\title{
Which U.S. Market Interactions Affect CEO Pay? Evidence from UK Companies
}

\section{Citation}

Gerakos, Joseph, Joseph Piotroski, and Suraj Srinivasan. "Which U.S. Market Interactions Affect CEO Pay? Evidence from UK Companies." Management Science 59, no. 11 (November 2013).

\section{Published Version}

http://pubsonline.informs.org/doi/abs/10.1287/mnsc.2013.1714

\section{Permanent link}

http://nrs.harvard.edu/urn-3:HUL.InstRepos:29660919

\section{Terms of Use}

This article was downloaded from Harvard University's DASH repository, and is made available under the terms and conditions applicable to Open Access Policy Articles, as set forth at http:// nrs.harvard.edu/urn-3:HUL.InstRepos:dash.current.terms-of-use\#OAP

\section{Share Your Story}

The Harvard community has made this article openly available.

Please share how this access benefits you. Submit a story.

Accessibility 


\title{
Which U.S. Market Interactions Affect CEO Pay? Evidence from U.K. Companies *
}

\author{
Joseph J. Gerakos \\ University of Chicago \\ Booth School of Business \\ joseph.gerakos@chicagobooth.edu \\ Joseph D. Piotroski \\ Stanford University \\ Graduate School of Business \\ jpiotros@stanford.edu \\ Suraj Srinivasan \\ Harvard Business School \\ ssrinivasan@hbs.edu
}

August 2012

\section{Forthcoming: Management Science}

\begin{abstract}
This paper examines how different types of interactions with U.S. markets by non-U.S. firms are associated with higher level of CEO pay, greater emphasis on incentive-based compensation, and smaller pay gap with U.S. firms. Using a sample of CEOs of U.K. firms and using both broad cross-sectional and narrow event-window tests, we find that capital market relationship in the form of an U.S. exchange listing is related to higher U.K CEO pay; however, the effect is similar when U.K. firms have a listing in any foreign country implying a foreign listing effect not unique to the U.S. Product market relationships measured by the extent of sales in the U.S. by U.K. companies are associated with higher pay, greater use of U.S.-style pay arrangements, and a reduction in the U.S.-U.K. pay gap. The product market effect is incremental to the effect of a U.S. exchange listing, the extent of the firm's non-U.S. foreign market interactions, and the characteristics of the executive. The U.S-U.K. CEO pay gap reduces in U.K. firms that make U.S. acquisitions. Further, the firm's use of a U.S. compensation consultant increases the sensitivity of U.K. pay practices to U.S. product market relationships.
\end{abstract}

\footnotetext{
* This paper benefited from the comments of Bart Dierynck (discussant), Jennifer Gaver (discussant), Stuart Gillan, Sudarshan Jayarman (discussant), Steve Kaplan, Kai Li (discussant), Christian Leuz, Krishna Palepu, Doug Skinner, Abbie Smith, George Yang (discussant), participants at Baruch College, the Center for Accounting Research and Education's 2008 Conference on Cross-Border Valuations, The Chinese University of Hong Kong's 2008 Accounting and Finance Workshop, the University of North Carolina's 2009 Global Issues in Accounting Conference, Harvard Business School's 2009 International Research Conference, Harvard Business School's 2009 Information, Markets, and Organizations Conference, the 2010 AAA Management Accounting Section mid-year meetings, the 2010 AAA FARS mid-year meetings, the 2010 London Business School Accounting Symposium, the 2011 EAA annual meetings, two anonymous referees, the Associate Editor, and the Editor. Stephanie Olivia, Jing Liu, and Jesse Lamarre-Vincent provided excellent research assistance.
} 


\title{
Which U.S. Market Interactions affect CEO Pay? Evidence from U.K. Companies
}

\begin{abstract}
This paper examines how different types of interactions with U.S. markets by non-U.S. firms are associated with higher level of CEO pay, greater emphasis on incentive-based compensation, and smaller pay gap with U.S. firms. Using a sample of CEOs of U.K. firms and using both broad cross-sectional and narrow event-window tests, we find that capital market relationship in the form of an U.S. exchange listing is related to higher U.K CEO pay; however, the effect is similar when U.K. firms have a listing in any foreign country implying a foreign listing effect not unique to the U.S. Product market relationships measured by the extent of sales in the U.S. by U.K. companies are associated with higher pay, greater use of U.S.-style pay arrangements, and a reduction in the U.S.-U.K. pay gap. The product market effect is incremental to the effect of a U.S. exchange listing, the extent of the firm's non-U.S. foreign market interactions, and the characteristics of the executive. The U.S-U.K. CEO pay gap reduces in U.K. firms that make U.S. acquisitions. Further, the firm's use of a U.S. compensation consultant increases the sensitivity of U.K. pay practices to U.S. product market relationships.
\end{abstract}

Keywords: CEO compensation, corporate governance, incentives, cross-listing, globalization. 


\section{Introduction}

Prior research documents that U.S. CEOs are more highly paid than their foreign peers (Abowd and Bognanno 1995, Conyon and Murphy 2000, Fernandes et al. 2011). These differences are primarily due to U.S. firms' greater reliance on long-term, incentive-based compensation. Such incentive-based compensation leads to pay packages that are sensitive to firm performance and have the potential for large payouts (Hall and Liebman, 1998). Despite these differences, recent worldwide evidence points toward higher levels of CEO pay and a greater reliance on incentive pay globally (Thomas 2008, Conyon et al. 2010, Conyon et al. 2011, Fernandes et al. 2011). In this paper, we examine how different types of interactions with U.S. markets lead non-U.S. firms to increase the level of CEO pay, to rely more on incentive pay, and to close the pay gap with U.S. firms.

Cheffins (2003) posits that non-U.S. firms have an incentive to structure pay packages similar to those in U.S. firms if they possess U.S. operations, face U.S.-based competitors, are exposed to the U.S. legal and regulatory environment, or employ executives capable of managing a U.S. company. The incentive to adopt U.S.-style pay arises from (1) the need to eliminate internal and external pay disparities arising from having U.S. operations and acquiring U.S. companies, (2) the impact of the U.S. legal regime on managerial responsibility and risk, and (3) competition to hire and retain global talent.

Local institutional factors can, however, mitigate the influence of these cross-border market forces on local pay practices (Bebchuk and Roe 1999). These factors include local governance mechanisms that differ from those in the U.S.; stakeholder pressure (e.g., labor unions); pay restrictions under corporate law; cultural and societal norms; media scrutiny and political outrage; and poorly developed capital markets that limit the use of option and equity-based pay. ${ }^{1}$

Using data on pay practices of 416 publicly traded U.K. firms from 2002 to 2007, we test the proposition that exposure to U.S. markets influence compensation practices in foreign firms. We measure three forms of the U.K. firms' interactions with U.S. markets: exposure to U.S. capital markets measured by the presence of a U.S. exchange listing; exposure to U.S. product markets measured by the relative importance of U.S. sales to the firm; and operational exposure to the U.S. measured by the extent of prior U.S. acquisition activity. We also measure analogous variables relating to the firms' non-U.S. foreign market interactions. ${ }^{2}$ Each construct captures a distinct channel by which the firm's U.S. and non-U.S. foreign market interactions can influence its pay practices. To the extent that U.S. market interactions create compensation-related pressures, pay practices at the U.K. firms should display stronger association with measures of U.S. market interactions than with the analogous non-U.S. foreign interactions.

\footnotetext{
${ }^{1}$ In many countries, provisions in corporate law, tax rules, and "soft law," such as corporate governance codes, can influence pay practices. For example, mandated shareholder voting on pay schemes (e.g., "say on pay” in the U.K.) allows for greater exercise of shareholder power, which can mitigate higher pay levels.

${ }^{2}$ In all cases where we use the label "non-U.S. foreign” we refer to “non-U.S. non-U.K.” countries.
} 
Our main tests are cross-sectional - we examine the variation in U.K. CEO pay in relation to the three economic interactions mentioned above. We also conduct two other tests to corroborate the main findings. First, since the incentive to adopt U.S.-style pay is greatest around the initiation or expansion of U.S. activities, we examine pay around two distinct events, a U.S. acquisition and a U.S. listing. These tests allow us to better isolate the distinct events that are associated with the observed pay differences. Second, we implement a propensity score based matched sample design where we examine the difference in CEO pay between U.K. firms and comparable U.S. firms ("pay gap”) as a function of the three types of economic interactions. If U.S. economic interactions make U.K. CEO pay similar to U.S. CEO pay, we would expect to observe a negative relation between the pay gap and proxies for U.S. exposure.

We find that the CEO pay practices of U.K. firms relate to their level of U.S. market exposure. First, total pay and incentive-based pay increase with the firm's exposure to U.S. product markets (U.S sales ratio) and the presence of U.S.-based operations (prior U.S. acquisitions). In contrast, non-U.S. foreign sales have only a limited impact on the cash-based pay of U.K. CEOs, and neither non-U.S. foreign sales nor non-U.S. foreign acquisitions are associated with observed levels of incentive-based pay. These results are notable given that non-U.S. foreign sales and non-U.S. foreign acquisitions are more prevalent than the corresponding U.S. activities in the sample. Second, in terms of capital market exposure, U.K. firms with a U.S. exchange listing award higher CEO pay (in the form of salary but not incentive pay) than firms without a U.S. listing. However, this higher pay is statistically similar to pay in firms with non-U.S. foreign exchange listings suggesting a general foreign listing effect not unique to a U.S. listing. Third, we find that the difference between the pay of a U.K. CEO and the pay of a CEO at a comparable U.S. firm decreases with the level of the U.K. firm's U.S. sales and acquisition activity but not when there is a U.S. listing, consistent with the reduction of pay disparities arising from the firm's interaction with the U.S. markets via the product market and its operational activities.

In addition to these economic interactions, we examine CEO's personal and professional ties to the U.S. and other foreign countries. U.K. executives who serve on foreign boards earn more than their U.K. peers who do not; however, this premium is the same for both U.S. and non-U.S. foreign board service. Moreover, we find no significant associations between U.K. pay practices and the executives' education background and nationality after controlling for other firm-level activities and CEO attributes.

Next, we extend these analyses to examine the influence of four governance mechanisms by which U.S. pay practices can be transmitted to non-U.S. firms and potentially increase the sensitivity of U.K. pay to U.S. market activity. These channels are: U.S. board experience of the firm's directors, use of U.S. compensation consultants, presence of U.S. institutional ownership, and use of U.S. companies in the compensation peer group. We find that the sensitivity of U.K. pay to the presence of U.S. activities is greater for firms that employ U.S. compensation consultants, consistent with this practice being a 
transmission mechanism for pay practices. In contrast, U.S. institutional ownership, U.S. board experience, and U.S. peer group companies do not alter the sensitivity of U.K. pay to U.S. interactions.

The event and matched sample tests confirm our basic findings. First, CEOs of U.K. firms experience an increase in both total pay and incentive-based pay after their firm makes a U.S. acquisition but not after non-U.S. foreign acquisitions. The matched sample tests show a lower pay gap between U.K. and U.S. CEO pay when U.S. sales ratio is higher but no relation with non-U.S. foreign sales. Further, U.S.-U.K. CEO pay gap reduces after U.S. acquisitions but not after other foreign acquisitions. Second, there is a significant increase in salary after a U.S. listing but, consistent with our cross-sectional results, a similar effect exists around non-US foreign listings as well. In the matched sample tests, a U.S. listing does not create decline in the pay gap between U.K. and matched U.S. firm CEOs once we control for product market links. These findings corroborate the cross-sectional results and are robust to controlling for pay trends over the sample period and for firms without CEO turnover in the event window.

We contribute to a small set of papers that examines the influence of global market interactions on CEO compensation in foreign firms. Fernandes et al. (2011) examine the U.S. pay premium across 26 countries using one year of data. Our study complements that paper by examining, in greater depth, a sample of firms from one country. Our focus on one country allows us to use more granular data on the geography of foreign exposure (U.S. versus non-U.S. activity), the different types of market interactions (capital, product, and operational), individual characteristics (director and CEO board experience, nationality, and education), and potential channels by which governance practices are transferred (U.S. board experience, use of U.S. compensation consultants, U.S. institutional ownership, and peer groups). Furthermore, unlike their one year of data, our time series data allow us to conduct event studies that control for firm- and executive-level unobserved heterogeneity.

In a related study, Carter et al. (2009b) compare CEO compensation between U.S. firms and a sample of European companies from 2003 through 2007 and find that the pay gap shrinks over time. Similar to our study, they examine whether pay is higher when the CEO is an American and when the board includes U.S.-based directors. However, this contemporaneous paper also does not examine the wider range of U.S. product market, capital market, and operational interactions included in our study, nor does it exploit time-series changes in firm-level U.S. market exposures; these limitations produce an incomplete picture of how U.S. market interactions shape foreign pay practices and increase the risk of their results arising from omitted firm or executive-level characteristics.

Lastly, Sapp (2008), Southam and Sapp (2010), and Conyon et al. (2011) document that U.S. listings by Canadian and U.K. firms are associated with an increase in foreign executives' pay. Our analysis extends their findings by examining the effect of U.S. product market and operating activities and CEO and board characteristics in addition to the U.S. listing. Furthermore, we benchmark the U.S. 
listing effect by comparing it with other non-U.S. foreign exchange listings. While we confirm the U.S. listing result documented in these papers we also show that there is a similar effect for non-U.S. foreign listings. This result suggests that any foreign listing, not just a U.S. listing, contributes to higher pay. Unlike these papers, we examine product market interactions and find that U.S. product market interactions have an impact on pay which is not exhibited when firms interact with non-U.S. foreign product markets.

We provide several important insights relative to this extant literature. First, we extend the literature by considering multiple dimensions of the firm's and CEO's interactions with U.S. markets and exploring the relative importance of different U.S. and foreign interactions. This feature of our research design also mitigates concerns about correlated omitted variables. Second, our cross-sectional and eventstudy tests produce consistent evidence that the existence and initiation of U.S. operations through acquisitions in the U.S. by U.K. firms are associated with a shift toward higher pay, greater use of incentive-based pay, and a reduction in the U.K.-U.S. pay gap. These effects are separable from the effect of U.S. listing and are not simply capturing an expansion of global business activity or operational complexity per se. Third, we benchmark each U.S. interaction effect with a non-U.S. foreign interaction. We show that both U.S. and non-U.S. foreign listings are associated with an increase in average salaries. Moreover, U.S. listings are not associated with greater incentive-based pay or with a reduction in the U.S.-U.K. pay gap once we control for the extent of U.S. product market exposure. Overall, the impact of U.S. listing is statistically indistinguishable from that of non-U.S. foreign listings calling into question results in prior literature cited above on the unique impact of U.S. listings on foreign CEO pay. Fourth, we show that the use of U.S. compensation consultants increases the sensitivity of U.K. pay to U.S. operational activities. Taken together, our results are consistent with cross-border, foreign market interactions influencing home-country pay practices and highlight market-based channels through which U.S.-style pay practices may transfer worldwide.

\section{Data and Research Design}

Our principle research design examines the association between U.K. compensation practices and proxies for U.S. market interactions. We focus on U.K. firms for several reasons. First, the U.S. and the U.K. have a long history of economic interdependencies, and a significant number of U.K. firms access U.S. capital and product markets, and possess U.S.-based operations. Second, the market for U.S. and U.K. executive talent likely spans both countries. Because the U.S. and U.K. share a common language, legal traditions, and customs, the costs associated with a U.S. executive living and working in the U.K. are lower relative to other countries, and vice versa. The resulting executive mobility increases the 
likelihood that U.S. market forces affect the pay packages of U.K. executives. ${ }^{3}$ Third, despite these strong ties, there are meaningful differences in executive pay practices. U.K. CEOs historically earn less than their U.S. counterparts and receive less incentive-based pay, although more recent data suggest that U.K. pay packages are trending toward U.S. levels (Towers Perrin 2001, Conyon and Murphy 2000, Conyon et al. 2011). Fourth, U.K. firms are required to disclose information on executive compensation packages, providing a source of high-quality compensation data. ${ }^{4}$ Fifth, by focusing on one country, we hold constant the legal, regulatory, political, cultural, and economic factors that can lead to correlated omitted variable problems in multi-country studies. Sixth, we can collect more granular data without concerns about the cross-country availability, comparability, and quality of information. ${ }^{5}$ Finally, many of the institutional arrangements in the U.K., including strong legal systems and investor protections, diffuse ownership structures, and sophisticated financial markets, are amenable to the use of U.S.-style, performance-based pay arrangements; as such, several of the countervailing forces outlined in Bebchuk and Roe (1999) are likely to be attenuated in the U.K. setting.

Together, these factors suggest that the U.K. provides a good sample to test the effects of U.S. market interactions on non-U.S. executive pay practices. Moreover, the failure to document a relation in the U.K. setting would cast doubt on arguments that U.S. market interactions influence the compensation arrangements and governance practices of non-U.S. firms.

\subsection{Sample Construction}

Our dataset on pay practices of publicly traded U.K. firms is from Hemscott (part of Morningstar, Inc.). It includes detailed data on CEO pay in 445 publicly traded U.K. firms from 2002 to 2007 (1,646 firm-year observations) as well as data on board composition, director and executive stock holdings, and corporate financial information. To be included in the final sample, we require each firm to have accounting, stock price, and governance data to implement our primary empirical tests. Firm-level financial data are from Hemscott, Datastream, and company annual reports. Stock price data are from Datastream. Data on U.S. and non-U.S. foreign board experience and CEO education background are from Boardex and hand-collected from annual reports. These data requirements result in a final sample of 1,543 firm-year observations from 416 unique U.K. firms over the period 2002-2007.

\subsection{Measurement of Executive Compensation Practices}

We identify five components of compensation for U.K. executives: salary, bonus, benefits-inkind, option grants, and restricted stock grants. We define Cash compensation ${ }_{i t}$ as the sum of Salary ${ }_{i t}$, Benefits-in-kind $_{i t}$, and Bonus $s_{i t}$; Equity compensation $_{i t}$ as the sum of the value of option grants and

\footnotetext{
${ }^{3}$ Consistent with this greater mobility, the U.K. hosts more U.S. expatriates than any other country outside North America.

${ }^{4}$ For example, even ADR firms are not required to comply with U.S. executive compensation disclosure requirements.

${ }^{5}$ A number of prior papers, including Kaplan (1994a, b), have adopted a single-country research design while exploring questions relating to comparative governance.
} 
restricted stock grants; and Total compensation $_{i t}$ as the sum of Cash compensation ${ }_{i t}$ and Equity compensation $_{i t}$. The value of option grants and restricted stock grants is the fair market value on the grant date. For option grants, we use the Black-Scholes formula assuming a 10-year life for the options. We use five-year U.K. government bond yields for the risk-free rate and estimate volatility using daily returns starting 260 calendar days and ending 111 calendar days before the fiscal year-end of the grant. Dividend yields are from Datastream. ${ }^{6}$

To measure the extent of the use of incentive-based pay, we define Equity ratio it $_{\text {it }}$ as the ratio of Equity compensation $_{i t}$ to Total compensation ${ }_{i t}$. Given the subjective nature of the assumptions in valuing option grants (e.g., time to exercise, vesting period, volatility, and potential for re-pricing), we also construct an indicator variable Option grant it $_{\text {to }}$ equal one if the executives received an option grant in a given year, and zero otherwise, to reflect the use of option-based pay by the firm.

\subsection{Measurement of U.S. Market Interactions and Expected Impact on U.K. Compensation}

This section discusses several potential paths by which firm-level U.S. interactions can shape pay practices and the variables we use to measure a U.K. firm's exposure to specific U.S. and global markets.

2.3.1 U.S. Product Markets. To attract and retain high-quality managerial talent, non-U.S. firms expanding into or selling in the U.S. must offer their U.S.-based executives competitive pay packages. However, if U.S.-based executives are paid more than their firm's home-country peers, pay disparities will arise within the organization. To alleviate adverse incentive, effort, and retention effects arising from internal pay disparities, non-U.S. firms would have to revise their home-country pay to better align with U.S. pay levels and composition. We capture the relative importance of foreign sales by the percentage of the firm's total sales generated in the U.S. and non-U.S. foreign markets each year, denoted as U.S. Sales Ratio $_{i t}$ and Non-U.S. Sales Ratio ${ }_{i t}$. Geographical sales data are obtained from each firm's annual report. ${ }^{7}$

2.3.2 U.S. Operations. A similar misalignment arises if a foreign firm acquires a U.S. company whose executives are compensated differently from those in the acquiring firm. ${ }^{8}$ The acquiring firm would have an incentive to adopt U.S.-style pay to minimize pay inequalities across global business units. We predict that U.K. firms with greater levels of U.S. operations are more likely to align their compensation with U.S. practices, both in terms of the level of pay and the use of incentive-based pay (i.e., composition of pay). Moreover, we hypothesize that non-U.S. foreign operations do not produce similar pay effects, as they are less likely to generate internal pay disparities.

\footnotetext{
${ }^{6}$ As discussed by Carter et al. (2009a), many U.K. firms attach absolute or relative performance-vesting conditions to equity grants. Our estimates of the value of restricted stock and option grants may therefore be upwardly biased.

${ }^{7}$ We recognize that our sales measure is an imperfect proxy for the scope of sales operations in the U.S. To the extent that the U.K. firm simply exports product to the U.S. market or has only limited selling operations (e.g., uses a foreign sales corporation for distribution purposes only), our sales variable captures the scope of product market interactions with the U.S. with error.

${ }^{8}$ The acquisition of Chrysler by DaimlerBenz AG is an example of such a transaction. The U.S. executives of Chrysler were paid substantially more than their German counterparts at DiamlerBenz. These differences in compensation practices created significant integration issues for the combined firm. See Blasko et al. (2000) for details.
} 
We capture the relative size of the U.K. firms' foreign business units acquired through M\&A activity by the percent of total assets derived from historical foreign M\&A. ${ }^{9}$ We define the variable U.S. Acquisition Ratio $_{i t}$ as the cumulative value of all U.S. acquisitions made by the U.K. firm between 1985 and year $t$, scaled by the firm's total assets at the end of year $t$. We define Non-U.S. Acquisition Ratio ${ }_{i t}$ as the cumulative value of all non-U.S. foreign (non-US, non-UK) acquisitions made by the U.K. firm between 1985 and year $t$, scaled by the firm's total assets at the end of year $t$. All acquisition ratios are log transformed because of skewness in the data. M\&A data are from Thomson's SDC database. ${ }^{10}$

2.3.3. U.S. Stock Exchange Listing. Any foreign firm that lists on a U.S. exchange is required to comply with U.S. securities laws and related regulations, including the Sarbanes-Oxley Act and the Foreign Corrupt Practices Act; its executives are exposed to the potential civil and criminal penalties of the litigious U.S. legal environment. ${ }^{11}$ Additionally, listing firms need to employ executives capable of navigating the reporting and governance requirements associated with a U.S. listing and the nuances of raising capital from U.S. investors. For these reasons, we expect CEOs of U.K. firms with a U.S. exchange listing to demand compensation similar to that of CEOs at publicly traded U.S. firms. ${ }^{12}$

We measure listing on a U.S. exchange by an indicator variable U.S. Listing $_{i t}$ that equals one if the U.K. firm's equity shares are listed on a U.S. exchange in year $t$, and zero otherwise. An analogous indicator variable, Non-U.S. Listing $_{i t}$, is set equal to one if the firm's equity shares are listed on a non-U.S. foreign stock exchange at the end of 2007, and zero otherwise. ${ }^{13}$ We obtain data on U.S. exchange listings from the Bank of New York ADR database. Data on non-U.S. exchange listings are from Datastream.

\subsection{Measurement of CEO Characteristics and Expected Impact on U.K. Compensation}

In addition to the firm's U.S. market interactions, the global personal and professional ties of the CEO could also influence the executive's pay package. To the extent that U.K. executives possess the skills to manage a U.S. company, are willing work in the U.S., and have credible U.S. employment opportunities, we expect them to demand compensation arrangements similar to their U.S. counterparts.

\footnotetext{
${ }^{9}$ An alternative approach to measuring operational exposure to the U.S. is to identify the percent of the firm's total assets located in the U.S. and in non-U.S. foreign markets. Unfortunately, asset-based geographical data for U.K. firms have two limitations: (1) geographical asset data is provided with less frequency and more coarsely than geographic sales data and (2) many U.K. firms report net assets (assets minus liabilities), not total identifiable assets, in their geographical segment reports. In robustness tests (not tabulated) we find that our results and inferences are robust to the use of both a U.S. asset ratio variable and an indicator variable denoting firms with more than $10 \%$ of net assets located in the U.S.

${ }^{10}$ Ideally, our measurement of cumulative historical foreign acquisition activity would extend to the start of the firm; however, we are limited by a lack of complete, historical transaction data and transaction values before 1985. To the extent that U.S. and non-U.S. acquisition activity is measured with error, the presence of long-term foreign operations will also be captured by the firm's foreign sales ratios.

${ }^{11}$ Consistent with this greater litigation risk, Seetharaman et al. (2002) find that U.K. auditors charge higher fees when their clients cross-list in the U.S., but not when the clients cross-list in non-U.S. markets.

${ }^{12}$ Similar reservation wage arguments exist to the extent that exposure to the U.S. product markets and U.S. operations subjects the non-U.S. executive to additional legal risks and responsibilities, such as product liability and discrimination laws.

${ }^{13}$ Our measure of the presence of non-U.S. foreign stock exchange listings is limited to firm-initiated listing decisions. We exclude listings on exchanges that can be investor-initiated or that limit the firm's formal external reporting requirements, such as the Frankfurt Stock Exchange’s Open (Unregulated) Market.
} 
We identify three individual characteristics that capture the executive's exposure to the U.S.: U.S. nationality, U.S. educational background, and U.S. board experience.

We set the indicator variable U.S. Nationality No $_{j}$ one if BoardEx identifies the executive's nationality/citizenship as American, and zero otherwise. We set the indicator variable U.S. Education $n_{j}$ to one if the U.K. executive received a bachelor's degree or higher from a U.S. institution, and zero otherwise. The indicator variable CEO U.S. Board Experience ${ }_{i t}$ is equal to one if the U.K. firm's CEO serves as a board member of a publicly traded U.S. corporation in year $t$, and zero otherwise. Analogous indicator variables, CEO Non-U.S. Foreign Nationality, CEO Non-U.S. Foreign Education, and CEO Non-U.S. Board Experience ${ }_{i t}$, equal one if, respectively, the executive's nationality/citizenship is neither U.K. nor U.S., the executive received a degree from a non-U.S. foreign institution, or the executive serves as a member of a non-U.S. foreign board in year $t$; they are zero otherwise.

\subsection{Descriptive Statistics}

Table 1 presents descriptive statistics for our sample. In terms of financial attributes (Panel A), firms tend to be both large and profitable, with mean (median) total assets of $£ 16.67$ billion ( $£ 1.35$ billion), mean (median) market capitalizations of $£ 4.89$ billion ( $£ 1.10$ billion), and mean (median) return on assets of 0.09 (0.08). There is, however, considerable variation in firm size and performance across our sample; more than $25 \%$ of the sample firms have total assets of greater than (less than) $£ 4.5$ Billion ( $£ 600$ million), and possess a return on assets greater than (less than) 0.13 (0.04). In terms of governance attributes, the mean board size is 9.7 directors, $41.0 \%$ of the directors are classified as insiders, and executives own, on average, $1.38 \%$ of outstanding shares. Finally, the mean (median) CEO is 52 (52) years old with a mean (median) tenure of approximately five (four) years.

Sample firms engage in extensive foreign market activity (Panel B). The mean firm generates $42 \%$ of total revenue from foreign product markets, $54 \%$ of firms have engaged in foreign M\&A activity, and $29 \%$ list shares on a foreign exchange. Focusing on the U.S., the average firm generates $15 \%$ of total revenue from the U.S., yet more than half of the firms generate no U.S. revenue. Thirty-eight percent of firms have engaged in a U.S. acquisition and $26 \%$ are listed on a U.S. exchange.

Consistent with prior research, the compensation arrangements of our U.K. firms are heavily tilted toward cash-based pay (see Panel C). The mean CEO earns a total annual sum of £1,511,730 of which $£ 921,822$ is cash compensation. The median CEO earns less than one million pounds; median cash and equity-based pay are $£ 714,000$ and $£ 200,000$, respectively. This composition is also reflected in the mean and median equity ratios of 0.25 and $0.23 .^{14}$

\footnotetext{
${ }^{14}$ Consistent with prior findings, compensation levels are increasing for U.K. CEOs over the sample period (results not tabulated for parsimony). Except for the elevated levels reported for 2002, mean (median) total compensation increased steadily from $£ 1.25$ ( $£ 0.89)$ million in 2003 to $£ 1.88$ ( $£ 1.25)$ million in 2007. The trend arises mainly from increases in incentive-based pay, both in the form of cash bonuses and equity-based compensation. The spike in mean compensation levels in 2002 is influenced by five
} 
Finally, panel D presents univariate comparisons of pay levels for firms with and without U.S. market exposure. Total pay, cash pay, equity pay, equity ratios, and option grant usage are all significantly higher along our three dimensions of the firm's U.S. interactions: U.S. sales activity, U.S. acquisitions, and U.S. exchange listing. Similarly, total pay, cash pay, and equity pay are all significantly higher for CEOs with individual-level ties to the U.S. labor market: U.S. citizenship, U.S. education, and U.S. board experience. These descriptive statistics do not, however, take into account the fact that firms with significant U.S. market interactions are likely to be larger, more complex organizations.

We also examine univariate correlations (untabulated) of firm-level attributes and the compensation practices of our U.K. firms and find that the latter are strongly correlated with firm size, board composition, stock ownership, and return volatility. Many of these firm-level attributes are also correlated with measures of U.S. market interactions; we control for these in the multivariate analysis.

In addition, the U.S. activities of U.K. firms tend to be correlated. For example, the correlation between U.S. Sales Ratio ${ }_{i t}$ and U.S. Acquisition Ratio $i$ is 0.47 , consistent with many firms establishing a U.S. product market presence through M\&A activity. Similarly, the correlation between U.S. Sales Ratio ${ }_{i t}$ and U.S. Listing it is 0.26 , consistent with prior evidence that foreign firms access the U.S. capital market for product market reasons (e.g., Pagano et al. 2002, Sarkissian and Schill 2004, Piotroski and Srinivasan 2008). The positive correlation of 0.18 (0.14) between U.S. Sales Ratio and CEO U.S. Education $_{j}$ (CEO U.S. Board Experience ${ }_{i t}$ ) highlights the impact of product market activities on labor market choices; in this case, U.K. firms appear to hire executives with U.S. educational and professional backgrounds to manage global businesses with U.S. operations. Together, these correlations highlight the importance of examining specific U.S. market interactions while controlling for other U.S. market activities.

Finally, U.K. firms' pay practices are positively correlated with the extent of the firms' U.S. market interactions. However, as noted earlier, these positive relations could simply reflect the awarding of greater pay to executives who manage larger, more complex operations; as such, all tests examining the relations between U.K. pay and U.S. market interactions will control for both firm size and the level of the firm's non-U.S. foreign market interactions. We outline, report, and discuss these tests below.

\section{Empirical Results}

To validate our U.K. compensation data and establish baseline relations between pay and firmlevel characteristics, we estimate several versions of the following pooled, cross-sectional model:

large option/equity grants (grants greater than $£ 10$ million). The Hemscott data is also subject to a potential large-firm bias in the first year (2002) of the database (e.g., mean and median market capitalizations are greater in 2002 than in 2003). 


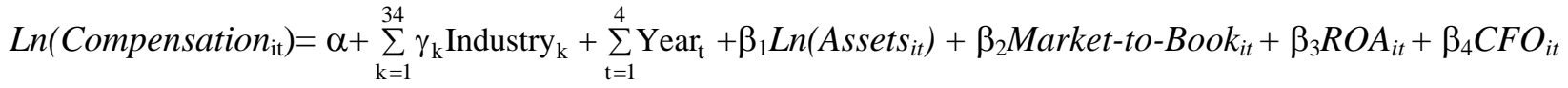

$+\beta_{5}$ Stock Return $_{i t}+\beta_{6}$ Return Volatility $_{i t}+\beta_{7} \operatorname{Ln}\left(\right.$ Tenure $\left._{i t}\right)+\beta_{8} \operatorname{Ln}\left(\right.$ Percent Shares Held $\left._{i t}\right)$

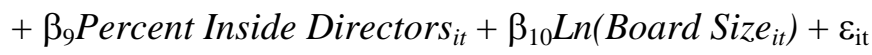

In these estimations, the dependent variable captures a specific dimension of each firm's compensation practices. ${ }^{15}$ For Total Compensation ${ }_{i t}$, Cash Compensation Cit Salary $_{i t}$, Bonus $i$, and Equity Compensation $_{\text {it }}$, the compensation variables are logarithmically transformed to control for the effects of heteroscedasticity and skewness. For estimations using Equity Compensation ${ }_{i t}$ and Equity Ratio Es $_{\text {it }}$ as the dependent variable, we use a Tobit model due to the substantial number of zero observations in the equity compensation data. For estimations using the indicator variable Option Grant ${ }_{i t}$ as the dependent variable, we use a logistic model specification.

In these cross-sectional models, we include common measures of the determinants of the level and composition of CEO pay. All variables are defined in Table $1 .{ }^{16}$ We include the natural logarithm of total assets, as larger firms are expected to hire more able CEOs with higher reservation wages (Baker and Hall 2004). We include the firm's market-to-book ratio to proxy for growth opportunities following Smith and Watts (1992). To control for firm performance, we include the firm's annual return on assets and stock return. We include the volatility of the firm's stock returns, as firm risk can lead risk-averse CEOs to demand premiums for performance-based pay. We also include annual cash flow, as firms with cash flow difficulties may grant higher levels of equity to conserve cash (Core and Guay 1999, 2001).

Core et al. (1999) show that corporate governance is related to the level of CEO pay. We therefore include in the cross-sectional models the log of the percent of shares held by the CEO and two measures of the firm's board structure: percent of inside directors and log of board size (Yermack, 1996). These and later regressions include industry and year fixed effects. Standard errors are clustered at the firm level. In untabulated results, these estimations corroborate basic relations between U.K. pay practices and firm attributes such as firm size and performance, as documented in prior research on U.S. firms.

\subsection{Influence of U.S. and Non-U.S. Foreign Market Interactions on U.K. Total Compensation}

Our first set of tests examines the association between the firm's aggregate foreign market interactions and its compensation practices. We expand equation (1) to include variables that capture the extent of the firm's total foreign sales, foreign acquisition activity, and foreign exchange listings. We estimate several versions of the following pooled, cross-sectional model:

\footnotetext{
${ }^{15}$ In these and subsequent analyses, we do not separately analyze benefits-in-kind. For our sample, this form of compensation is economically small $($ mean $=£ 46,383$; median $=£ 23,346)$ and displays limited variation across firms and over time.

${ }^{16}$ To eliminate the effect of outliers in our analysis, we winsorize the following variables at the 1st and 99th percentiles: Marketto-Book ${ }_{i t}, R_{i} A_{i t}, C F O_{i t}$, Stock Return ${ }_{i t}$, Return Volatility $y_{i t}$, and Percent Shares Held ${ }_{i t}$. All results are robust to winsorizing all variables at the 1st and 99th percentile.
} 
Ln(Total Compensation $\left.{ }_{\mathrm{it}}\right)=\alpha+\sum_{k=1}^{34} \gamma_{k}$ Industry $_{k}+\sum_{t=1}^{4}$ Year $_{t}+\sum_{j=1}^{10} \beta_{j}$ ControlVariables $_{j}$

$+\beta_{11}$ Foreign Sales Ratio $_{i t}+\beta_{12} \operatorname{Ln}\left(\right.$ Foreign Acquisition Ratio $\left._{i t}\right)+\beta_{13}$ Foreign Listing $_{i t}+\varepsilon_{\text {it }}$

We present select coefficients and standard errors (in parentheses) from these estimations in Table 2, Panel A. The first three columns present coefficients from the regression of total compensation on a specific dimension of each firm's foreign market interactions. The results reveal that the total pay for U.K. CEOs is significantly positively associated with the firm's level of foreign sales and listing on a foreign exchange. Estimated coefficients in the last column, where we include all three foreign market interaction variables, continue to exhibit significant positive relations between total compensation and the firm's foreign sales ratio and foreign listing decision. ${ }^{17}$

We next split our foreign market variables into measures of the firm's U.S. and non-U.S. foreign market interactions because we expect U.S. market interactions to have a more significant role in U.K. pay arrangements than non-U.S. foreign market interactions. Specifically, we expand equation (2) to include variables that capture the extent of the firm's total U.S. and non-U.S. foreign sales, U.S. and nonU.S. foreign acquisition activity, and U.S. and non-U.S. foreign exchange listings as follows:

Ln$\left._{(\text {Total Compensation }} \mathrm{it}\right)=\alpha+\sum_{k=1}^{34} \gamma_{k}$ Industry $_{k}+\sum_{t=1}^{4}$ Year $_{t}+\sum_{j=1}^{10} \beta_{j}$ ControlVariables $_{j}+\beta_{11}$ U.S. Sales Ratio $_{i t}+\beta_{12}$ Non-U.S. Sales Ratio ${ }_{i t}+\beta_{13} L n$ (U.S. Acquisition Ratio $)+\beta_{14} L$ n(Non-U.S. Foreign Acquisition Ratio $\left._{i t}\right)+\beta_{15}$ U.S. Listing $i t+\beta_{16}$ Non-U.S. Foreign Listing ${ }_{i t}+\varepsilon_{\mathrm{it}}$

Select coefficients and standard errors (in parentheses) from these estimations are presented in Table 2, Panel B. The results show that two measures of the firm's U.S. market interactions-U.S. Sales

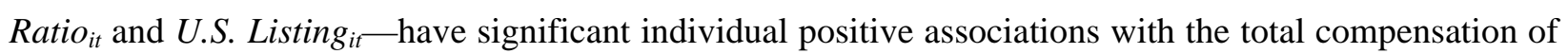
U.K. CEOs. To control for the impact of greater global activities per se, the models also include measures of the firm's total non-U.S. foreign activities. Any compensation premium related to the scope of global activities should be related to both U.S. and non-U.S. foreign sales and acquisition variables. Of the nonUS foreign interactions, only non-U.S. foreign listings display a significant association with total compensation, and the non-U.S. listing coefficients are statistically indistinguishable from the U.S. listing coefficients. Neither of the other two non-U.S. foreign market interactions, sales ratio and acquisition ratio displays a significant association with compensation practices, and the estimated coefficients on U.S. Sales Ratio ${ }_{i t}$ are significantly larger than the coefficients on Non-U.S. Foreign Sales Ratio ${ }_{i t}$.

\footnotetext{
${ }^{17}$ Given the positive correlations between these three variables, it is difficult to interpret the ultimate source of these positive relations. As noted in Table 2, foreign acquisition-related activity and foreign exchange listings have correlations of 0.42 and 0.24 with the firm's foreign sales ratio. Therefore, individual relations documented in the first four columns could be the result of a spurious correlation with another of the firm's foreign activities. For instance, firms may list on a foreign exchange prior to making an acquisition to allow for a stock based transaction. The inclusion of all three variables in the model helps control for potentially omitted variables, but introduces concerns about multicollinearity. For completeness, we present all four models.
} 
The last column presents results in which we include all three market interactions; after controlling for all factors, we continue to observe significant positive relations between total compensation and the firm's U.S. sales ratio and U.S. exchange listing, mirroring the aggregate foreign market interaction effects observed in Panel A. The full model estimation shows that the pay consequences of U.S. product market activities are incremental to the exchange listing effect documented in prior literature. While non-US Foreign Listing is not significant at conventional levels the coefficients on US listing are statistically indistinguishable from that of non-US foreign listing ( $\mathrm{p}$-value $=0.972$ ).

The differential sensitivity of U.K. pay to U.S. product market interactions versus analogous nonU.S. foreign product market interactions suggests that the positive coefficient on U.S. Sales Ratio it is not just capturing pay premiums for managing a more global or complex business, but instead reflects the unique compensation pressures created by participation in U.S. product markets. The failure to find an association between U.K. total pay and non-U.S. foreign activities, as proxied by sales and acquisition ratios, is especially interesting given that, for our sample firms, non-US foreign activities are more prevalent than US activities. For these firms, 28\% of total revenue is derived from non-US foreign sources and $50 \%$ of the firms engaged in non-US foreign acquisitions; the corresponding percentages for US-related activity are $15 \%$ and $38 \%$. These non-U.S. foreign results are also interesting in light of research suggesting that job complexity increases CEO compensation (e.g., Rose and Shepard 1997). ${ }^{18}$

In terms of economic significance, a $1 \%$ increase in U.S. sales is associated with a $0.65 \%$ increase in total compensation, which translates into a $£ 9,751$ increase when evaluated at the mean level of total compensation. On a relative basis, our estimations imply that a one percentage point increase in U.S. sales is associated with a $0.60 \%$ larger increase in total compensation than a corresponding similar increase in non-U.S. foreign sales. With respect to exchange listings, executives of firms that are cross-listed in the U.S. receive almost $23.6 \%$ more in total compensation than executives of firms not cross-listed on a foreign exchange, while executives of firms that cross-list in foreign locations other than the U.S. receive $19.0 \%$ more compensation than the executives of non-cross-listed firms. At the mean level of total compensation, these effects represent increases of $£ 356,768$ and $£ 287,229$.

\subsection{Influence of U.S. and Non-U.S. Market Interactions on the Components of U.K. Compensation}

Next, we re-estimate variations of equation (3) using the different components of pay as our dependent variables. These estimations, presented in Table 3, yield two key findings. First, U.S. activities are associated with greater use of incentive-based pay. Firms with larger U.S. sales award greater levels

\footnotetext{
${ }^{18}$ One potential explanation for the difference in results between U.S. and non-U.S. foreign activities is that the task of managing a firm with U.S. activities is significantly more challenging than managing a firm operating in other foreign markets. Both U.S. and non-U.S. foreign markets require the executive to manage foreign exchange rate risk, overcome geographic distance (e.g., US and Asian product markets are equally distant from the UK), navigate local regulations and institutional frictions, and understand local consumer preferences. On some dimensions, the U.S. environment may be more burdensome (e.g., litigation risk); on other dimensions, the U.S. offers fewer challenges (common language; property rights protection; less corruption).
} 
of bonus pay. Firms with higher U.S. sales and those with greater levels of historical U.S. acquisition activity are more likely to grant stock options than firms without corresponding U.S. product market or operational exposure. Greater levels of both U.S. and non-U.S. foreign sales are associated with greater total cash compensation, consistent with executives receiving a higher reservation wage for managing more complex, global businesses; however, the magnitude of the sensitivity of cash compensation to nonU.S. foreign sales activity is only half of that observed for U.S. sales activities. More importantly, unlike firms with U.S. activities, U.K. firms with non-U.S. foreign activities use significantly lower levels of bonus- and equity-based compensation; coefficients on U.S. Sales Ratio ${ }_{i t}$ (U.S. Acquisition Ratio ${ }_{i t}$ ) are

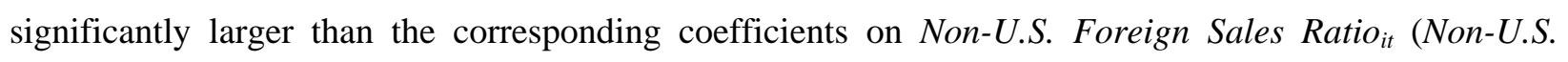
Foreign Acquisition Ratio $_{i t}$ ) in the bonus and equity ratio models (option grant model).

Second, U.S.-listed firms award executives higher salaries and cash-based pay than their nonlisted peers, but they do not increase incentive-based compensation. Moreover, we find a similar increase in cash compensation for other non-U.S. foreign exchange listings, with the magnitude of the compensation effects for U.S. listings statistically indistinguishable from non-U.S. foreign exchange listings. These results suggest that a U.S. listing does not create a demand for the use of U.S.-style incentive-based pay; instead, managers receive a higher reservation wage as compensation for bearing the risks and responsibilities associated with a foreign stock exchange listing.

Taken together, the results in Tables 2 and 3 suggest that interactions with U.S. product and capital markets are associated with higher levels of CEO pay for the sample U.K. companies. Each of these interactions has an incremental impact on total compensation, but the form of the additional pay depends upon the nature of the market interaction. U.S. sales are associated with a greater use of incentive-based pay. U.S. exchange listings are associated with greater levels of salary and cash-based pay, consistent with the firm's need to compensate the executive for bearing the additional risks and responsibilities associated with a U.S. exchange listing, but not creating a demand for U.S.-style incentive pay. Moreover, the listing effect appears to reflect a pay premium, or higher reservation wage, associated with managing a cross-listed entity in any foreign location not just in the U.S.

\subsection{Influence of CEO Characteristics and U.S. Market Interactions on U.K. Compensation}

To exploit CEO-level heterogeneity in our data, we next include CEO-level characteristics in our compensation models; this allows us to examine the incremental influence of CEO-specific personal and professional links to the U.S on U.K. compensation practices and to address concerns that omitted CEO attributes drive the firm-level results. Because we hypothesize that U.S. linkages have a greater impact on U.K. pay than non-U.S. foreign linkages, we split our CEO-level measures into the executive's U.S. and non-U.S. foreign characteristics. Specifically, we expand equation (3) to include variables that capture the 
CEO's U.S. and non-U.S. foreign nationality, educational background, and board experience, and estimate several versions of the following pooled, cross-sectional model:

Ln $\left._{\text {Total Compensation }} \mathrm{it}\right)=\alpha+\sum_{k=1}^{34} \gamma_{k}$ Industry $_{k}+\sum_{t=1}^{4}$ Year $_{t}+\sum_{j=1}^{10} \beta_{j}$ ControlVariables $_{j}+\beta_{11}$ U.S. SalesRatio $_{i t}$

$+\beta_{12}$ Non-U.S. Sales Ratio ${ }_{i t}+\beta_{13} \operatorname{Ln}\left(\right.$ U.S. Acquisition Ratio $\left.{ }_{i t}\right)+\beta_{14} L n\left(\right.$ Non-U.S. Acquisition Ratio $\left.{ }_{i t}\right)$

$+\beta_{15}$ U.S. Listing ${ }_{i t}+\beta_{16}$ Non-U.S. Listing ${ }_{i t}+\beta_{17}$ CEO U.S. Nationality ${ }_{i t}+\beta_{18} C E O$ Non-U.S. Foreign Nationality $_{i t}+\beta_{19}$ CEO U.S. Education ${ }_{i t}+\beta_{20}$ CEO Non-U.S. Foreign Education ${ }_{i t}+\beta_{21}$ CEO U.S. Board Experience $_{i t}+\beta_{22} C E O$ Non-U.S. Foreign Board Experience ${ }_{i t}+\varepsilon_{i t}$

We present select coefficients and standard errors (in parentheses) from these estimations in Table 4. The final column in this table includes the complete set of variables and best allows us to make inferences about total U.K. compensation. First, we find no association between U.K. compensation levels and the educational background of the firm's CEO. Second, we find that U.S. citizens receive greater compensation than their non-American peers; however, this difference disappears after controlling for other CEO characteristics, similar to the results in Carter et al. (2009b). Third, CEOs with foreign board experience receive greater compensation than executives lacking this background. This effect is observed regardless of whether the board experience was with a U.S. or non-U.S. foreign firm, suggesting that executives concurrently serving on foreign boards are simply more skilled than non-serving executives - in fact, the board invitations may stem from their reputation-and as such, they earn higher pay. ${ }^{19}$ Firm-level U.S. product market interaction measured by U.S. Sales Ratio ${ }_{i t}$, is related to higher U.K. CEO pay after controlling for all market interactions and individual characteristics (in the last column) and the effect is higher than the impact of non-U.S. Foreign Sales Ratio (p-value of difference in coefficients $=0.014)$. CEO pay is higher in firms with a U.S. listing but the level is statistically no different from pay in firms with non-U.S. foreign listings (p-value of difference in coefficients $=0.896$ )

\section{The Impact of U.S. Governance Dissemination Mechanisms on U.K. Compensation}

We extend the preceding firm-level analysis to examine four potential mechanisms by which U.S.-style pay practices can be transmitted to U.K. firms: the U.S. board experience of the firm's directors, the use of U.S. compensation consultants, the explicit use of U.S. firms as peers groups for compensation benchmarking, and the presence of U.S. institutional ownership. We posit that these channels allow the boards of U.K. firms to benchmark against U.S. pay practices and provide justification for adopting U.S.-style pay arrangements. We expect the sensitivity of U.K. compensation to U.S. market activities to be greater in presence of these dissemination mechanisms.

\footnotetext{
${ }^{19}$ CEO foreign board service is a limited phenomenon in our U.K. data. Only 4\% (4\%) of our executives served on the board of a U.S. (non-U.S. foreign) company in our sample period. The board experience results are robust to the inclusion of a control for the executive's concurrent presence on another U.K. firm's board.
} 
Directors with U.S. Board Experience: The globalization of corporate boards can increase executive visibility among a geographically widespread director pool thus increasing managerial mobility globally and also facilitate cross-border transmission of corporate governance practices. The first effect requires local firms with global executive talent to pay U.S. market wages to retain these individuals; the second effect implies that local directors gain familiarity with U.S.-style pay mechanisms through U.S. board service, and that they bring such practices back to their home firms. To gauge a sample firm's exposure to this channel, we identify whether any of the firm's directors serves on a U.S. board. We set the indicator variable U.S. Board Experience $_{i t}$ to one if any of the U.K. firm's non-executive directors serves as a board member of a publicly traded U.S. corporation in year $t$, and zero otherwise.

U.S. Compensation Consultants: Foreign firms can hire U.S.-based compensation consultants to help resolve internal pay disparities inside the company, to provide guidance on market pay given the executive's responsibilities, and to develop compensation programs capable of recruiting and retaining global executive talent. We set the indicator variable U.S. Compensation Consultant ${ }_{i t}$ to one if the U.K. firm's proxy statements disclose the use of a U.S. compensation consultant in year $t$, and zero otherwise. Data on compensation consultants are taken from the Hemscott database.

U.S. Institutional Ownership: Large institutional investors have an incentive to monitor the activities of their portfolio firms. Through their holdings and influence, institutional investors can initiate governance changes that resolve agency conflicts between managers and shareholders. One such change is the adoption of performance-based pay. We define the variable U.S. Institutions ${ }_{i t}$ as the percentage of shares outstanding held by U.S. institutions in year $t$. Institutional ownership data are from Hemscott.

U.S. Peer Group: Prior research finds that firms manage peer groups to adjust CEO pay for retention and rent extraction purposes (Bizjak et al. 2008, Faulkender and Yang 2010). A U.K. firm with U.S. activities can include U.S. companies in its peer group to benchmark and justify its CEO's pay. We set the indicator U.S. Peer ${ }_{i t}$ to one if the U.K. firm includes a U.S. firm in its peer group in year $t$, and zero otherwise. Data are from remuneration committee reports in the company's annual report.

Finally, we create analogous non-U.S. foreign indicator variables for each of these four channels. Descriptive evidence on the prevalence of the channels is in Table 5, Panel A. We find that in $48.3 \%$ of our firm-years, companies use U.S. compensation consultants, and that $33 \%$ of the firms' boards have a director with U.S. board experience. Over half the firms in our sample had U.S. institutional ownership. In $12.7 \%$ of our firm-years, companies include a U.S. firm in the peer group. The prevalence of these activities in our sample suggests that these are plausible channels for the transfer of U.S. pay practices.

Table 5, panel B presents select coefficients from estimations of the following model: 
$\operatorname{Ln}($ Total Compensation it $)=\alpha+\sum_{k=1}^{34} \gamma_{k}$ Industry $_{k}+\sum_{t=1}^{4}$ Year $_{t}+\sum_{j=1}^{10} \beta_{j}$ ControlVariables $_{j}+\beta_{11}$ U.S. Sales Ratio $_{i t}+\beta_{12}$ Non-U.S. Foreign Sales Ratio ${ }_{i t}+\beta_{13} L n(U . S . \text { Acquisition Ratio })_{i t}+\beta_{14} L n($ Non-U.S. Foreign Acquisition Ratio $)_{i t}+\beta_{15}$ U.S. Listing $_{i t}+\beta_{16}$ Non-U.S. Foreign Listing ${ }_{i t}+\beta_{17}$ U.S. Channel ${ }_{i t}+\beta_{18}$ Non-U.S. Foreign Channel $_{i t}+\beta_{19}$ U.S. Sales Ratio ${ }_{i t}{ }^{*}$ U.S. Channel ${ }_{i t}+\beta_{20}$ Non-U.S. Foreign Sales Ratio ${ }_{i t}^{*}$ Non-U.S. Foreign Channel $_{i t}+\beta_{21} \operatorname{Ln}(\text { U.S. Acquisition Ratio) })_{i t} * U . S$. Channel ${ }_{i t}+\beta_{22} \operatorname{Ln}($ Non-U.S. Foreign Acquisition

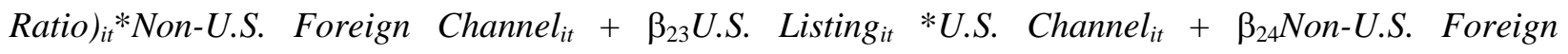
Listing $_{i t}{ }^{*}$ Non-U.S. Foreign Channel ${ }_{i t}+\varepsilon_{i t}$

In this model, the relation between total compensation and the presence of U.S. activities is conditioned upon the presence or usage of a specific U.S. and non-U.S. foreign governance channel, as denoted by the interaction with the variables U.S. Channel ${ }_{i t}$ and Non-U.S. Foreign Channel ${ }_{i t}$.

We find that the sensitivity of U.K. pay practices to the presence of U.S. operations is greater for firms that employ U.S. compensation consultants, consistent with this practice serving as a transmission mechanism for U.S. pay practices. Additionally, we find some evidence that the use of U.S. compensation consultants and the inclusion of a U.S. firm in the peer group are positively associated with higher levels of CEO compensation; however, U.S. institutional ownership, U.S. board experience, and U.S. peer group usage do not significantly alter the sensitivity of U.K. pay to U.S. activities. These results suggest that firms use compensation consultants as a channel to address pay disparities arising from U.S. activities.

\section{Event Tests: Compensation Practices around U.S. Market Events}

The incentive for U.K. firms to adopt U.S.-style pay arrangements will be greatest around the initiation, or material expansion, of U.S. activities. To corroborate the preceding cross-sectional evidence, we examine the trend in CEO pay of U.K. firms around two distinct events: a U.S. M\&A transaction and a U.S. exchange listing. Any observed shift in the amount and form of U.K. CEO pay around specific U.S. market events will sharpen the interpretation of our earlier results and mitigate concerns that the U.S. activity-level variables are simply capturing omitted firm and/or managerial characteristics. Moreover, by examining trends around an analogous set of non-U.S. foreign acquisition and listing events, we can better attribute the observed results to the unique compensation-related pressures created by U.S. markets.

\subsection{U.S. and Non-U.S. Acquisition Events}

The acquisition of a U.S. firm, especially one that is material in size relative to the acquiring U.K. firm, can create incentives to align both firms' compensation practices. To test for this acquisition effect, we identify all U.K. firms in the SDC database that made a U.S. acquisition over the sample period 20022007. We also identify the corresponding sample of U.K. firms that acquired non-U.S. foreign firms over the same period. To isolate the effect of a significant increase in foreign business activities via an 
acquisition, we include only those firms that did not engage in a foreign acquisition in the previous year. We require all event firms to have accounting and price data to measure our full set of control variables and sufficient compensation data to measure salary, bonus, cash compensation, equity compensation, and total compensation around the acquisition event. Because this analysis also includes acquiring UK firms not included in the Hemscott database, data for these additional firms were hand-collected from the respective companies' annual reports and from Datastream. These criteria result in a final sample of 32 (59) U.K. firms acquiring a U.S. (non-U.S. foreign) firm over our sample period. ${ }^{20}$

For each firm, we measure compensation levels in the years before, during, and after the acquisition events. We trend-adjust the yearly compensation data by removing the mean compensation level reported for all firms in the Hemscott database for that given calendar year. Using these data, we test for a shift in compensation around the acquisition event using the following multivariate model:

$$
\begin{gathered}
\text { Ln(Trend-adjusted Compensation } \left._{\mathrm{it}}\right)=\alpha+\sum_{i=1}^{j} \gamma_{k} \text { Executive }_{i}+\sum_{j=1}^{10} \beta_{j} \text { ControlVariables }_{j} \\
+\beta_{11} \operatorname{Ln}\left(\text { U.S. Acquisition Ratio }_{i t}\right)+\beta_{12} \operatorname{Ln}\left(\text { Non-U.S. Acquisition Ratio }{ }_{i t}\right)
\end{gathered}
$$

In these estimations, the coefficients on U.S. Acquisition Ratio $o_{i t}$ and Non-U.S. Acquisition Ratio ${ }_{i, t}$ capture the average, incremental increase in compensation around the identified U.S. and foreign acquisition event, after controlling for the executive, key firm-level characteristics (size, growth options, and performance), and earlier U.S. and non-U.S. foreign acquisition activity. Executive $_{i}$ is the executivelevel fixed effect to capture time-invariant firm and executive-level unobserved heterogeneity. This fixed effect specification means that the estimation will capture the change in acquisition ratio over the event period (i.e., acquisitions made in the preceding year).

Consistent with the cross-sectional results, Table 6 documents that CEOs of firms making a U.S. acquisition experience a significant increase in total and incentive-based compensation in the year after the acquisition. A similar shift, however, does not exist around non-U.S. acquisitions. ${ }^{21}$ The increase in both total and incentive-based pay around the U.S. event alone is consistent with U.K. acquirers attempting to resolve internal pay inequities arising from the acquisition. Finally, we re-estimate these models after eliminating firms with CEO turnover during the acquisition event windows, allowing us to estimate the impact of acquisition activity after holding the manager and his/her human capital constant. This criterion reduces the sample to 24 U.S. acquisition events and 45 non-U.S. foreign acquisition events. Panel B results show that the preceding results and inferences are robust to this sample.

\footnotetext{
${ }^{20}$ Descriptive statistics reveal that these events represent a material change in the firm's operations. The mean (median) U.S. acquisition represents $11.3 \%$ (4.0\%) of end-of-year total assets, while the mean (median) non-U.S. foreign acquisition represents $6.5 \%(2.4 \%)$ of ending total assets. This sample consists of 16 firms that engaged in both a U.S. and non-U.S. foreign acquisition during our sample period. The results of these event tests are robust to excluding these firms from the analysis.

${ }^{21}$ Additionally, the increases in salary, bonus, and option grants around U.S. acquisitions are significantly different than the estimated effects for non-U.S. foreign acquisitions.
} 


\subsection{U.S. and Non-U.S. Exchange Listing Events}

Foreign companies that list on a U.S. exchange are required to comply with the strict U.S. regulatory and governance environment; thus, their executives must assume greater risks and responsibilities. This exposure likely results in the demand for a higher reservation wage, reflecting an increase in the executive's cash compensation, and in particular, salary-based compensation, around a U.S. listing event. To examine this impact, we identify all publicly traded U.K. firms that engaged in the initial listing on a U.S. exchange over the period 1999-2006. ${ }^{22}$ We also identify the analogous sample of U.K. firms that engaged in a non-U.S. foreign exchange listing over the same period. We require all listing firms to have accounting and price data to measure a parsimonious set of control variables and sufficient compensation data to measure salary, bonus, cash pay, equity pay, and total compensation around the listing event. For those listing firms not in the Hemscott database, we gather data from the companies' annual reports and from Datastream. These criteria result in a final sample of 54 (8) U.K. firms engaging in a U.S. (non-U.S.) exchange listing over this period. ${ }^{23}$

For each firm, we measure compensation levels in the years before, during, and after the listing event. Cash pay, salary, and bonus amounts are trend-adjusted by removing the mean compensation level for all firms in the Hemscott database for that calendar year. Equity pay and total compensation are not trend-adjusted as we lack equity pay data in the Hemscott database for the early part of the event period. We test for a shift in compensation around the listing event with the following reduced-form model:

$\operatorname{Ln}\left(\right.$ Compensation $\left._{\mathrm{it}}\right)=\alpha+\sum_{\mathrm{i}=1}^{\mathrm{j}} \gamma_{\mathrm{k}}$ Executive $_{\mathrm{i}}+\beta_{1}$ Log $\left._{\left(\text {Assets }_{i t}\right)}\right)+\beta_{2}$ Market-to-Book $_{i t}+\beta_{3} R O A_{i t}$

$+\beta_{4}$ U.S. Listing Event ${ }_{i t}+\beta_{5}$ Non-U.S. Foreign Listing Event ${ }_{i t}+\varepsilon_{\mathrm{it}}$

U.S. Listing Event ${ }_{i t}$ and Non-U.S. Listing Event $t_{i t}$ are indicator variables equal to one in the year after the U.S. and non-US exchange listing, and zero otherwise. These indicator variables measure the mean, incremental increase in pay following the listing events, after controlling for executive- and firmlevel characteristics, size, growth options, and performance over the three-year window. Executive $e_{i}$ is an executive-level fixed effect to capture time-invariant firm- and executive-level unobserved heterogeneity.

These estimations, tabulated in Table 7, confirm our earlier cross-sectional analyses; both U.S. and non-U.S. exchange listings are associated with a significant increase in salary-based compensation following the listing event, and the magnitude of the two listing effects are statistically equivalent. Because a foreign listing changes the CEO’s responsibilities and required skill sets, we re-estimate these

\footnotetext{
${ }^{22}$ Our sample includes three firms that previously delisted from a U.S. exchange for performance reasons. Because these firms have been absent the U.S. regulatory and legal environment for at least seven years before their second listing, we include the latter as a new listing decision. The exclusion of these firms from our tests does not change the tenor of our results.

${ }^{23}$ Our sample selection criteria identified an additional 17 firms that engaged in both U.S. and non-U.S. exchange listings during our sample period. In each case, the two listing events occurred essentially simultaneously (within one month of each other). To avoid the confounding effects associated with simultaneous multiple foreign listings, our event analysis excludes these firms.
} 
models after eliminating firms with CEO turnover during the listing event windows (Panel B). The preceding results are robust to this change; in this particular subsample of 56 firms (50 U.S. and 69 nonU.S. exchange), the executive, and therefore the manager's human capital is held constant, yet he or she appears to be given a higher salary upon exposure to foreign capital markets. ${ }^{24}$

This analysis confirms our earlier cross-sectional findings that U.K. executives receive a higher reservation wage in the form of higher salary for bearing the additional legal liability and personal risk associated with exposure to U.S. and non-U.S. foreign capital markets. Furthermore, a U.S. listing does not lead to the adoption of U.S.-style incentive-based pay. Instead, executives earn a salary premium for the risk and effort associated with a foreign exchange listing, regardless of location of the listing.

\section{Additional Analyses}

\subsection{Evidence on Alleviation of Pay Disparity: Matched Firm Research Design}

If the observed positive relation between U.K. compensation and the extent of U.S. activities is due to U.K. firms attempting to alleviate pay disparities upon entering the U.S. market (Cheffins 2003), then the observed compensation gap between the U.K. firm and the relevant U.S. benchmark should decrease following the initiation or expansion of U.S. exposure.

To test this argument, we match each U.K. firm-year observation with a similarly sized U.S. firm in that year using propensity scores based on the firm-level characteristics included as control variables in equation (1). ${ }^{25}$ Using the matched U.S. firm's pay as a benchmark, we calculate the pay disparity for each U.K. firm-year observation. This variable, Pay Disparity ${ }_{i t}$ is measured as the log of the matched U.S. firm's total compensation minus the log of the U.K. firm's total compensation, and is expected to be decreasing in the extent of the U.K. firm's U.S. market activities. Evidence of greater similarity in compensation would be consistent with the elimination of pay disparities.

Results in Table 8 suggest that the pay gap of U.K. firms relative to matched U.S. firms is decreasing in the extent of U.S. sales activity (i.e., U.S. Sales Ratio ${ }_{i t}$ ) in our full cross-sectional sample. Moreover, in the acquisition event tests (Panel B), we observe greater similarity in pay levels between

\footnotetext{
${ }^{24}$ Foreign listing can also be related to foreign product market decisions, e.g., M\&A activity or foreign operations. Estimations including controls for a shift in U.S. and non-U.S. foreign operations (Sales Ratio and Acquisition Ratio) yield similar inferences. ${ }^{25}$ To implement the propensity score matches, we carry out a 1-to-1 nearest neighbor match without replacement. In order to maximize sample size, we do not use a cut off value. This approach yields no significant differences between the treatment and control firms along the major dimensions of the firm that affect compensation i.e., firm size, growth opportunities, accounting performance, and stock return performance. There are, however, significant differences on other dimensions, especially relating to corporate governance. In the tests in Table 8, we regress the differences in compensation (pay gap) on the U.S./Non-U.S. interaction variables and include the differences in these control variables to capture any variation not picked up in the propensity score matches. We also implemented several additional analyses to evaluate the sensitivity of our results to the matching criteria. First, we performed a simple match based on size within industry and year. The results for these untabulated tests are quantitatively and qualitatively similar to those presented in Table 8. Second, we used a cut off value of 0.02 in our propensity score algorithm. At this cut off value, the sample size drops from 1,542 to 652 observations. The results for this test are similar to the results reported in Table 8 without the use of a cut off value.
} 
matched U.K. and U.S. firms following U.S. acquisitions. This significant decrease in the pay gap during the event window is notable as the matching process takes into account the effect of changes in size, profitability, and growth options on compensation in the U.K. firm following the acquisition event; as such, these matched sample event tests capture movement towards U.S. pay following an increase in the scope of U.S. operations. Finally, in contrast to the U.S. sales and acquisition results, we find that foreign listings do not result in similarity in pay in our levels specification after we control for U.S. operational activity or in the event specification once we control for CEO turnover. The disappearance of the U.S. listing effect on the pay gap once we include the U.S. operations variables is noteworthy given the conclusions in Southam and Sapp (2010) and Conyon et al. (2011) that U.S. listing causes U.K. firms to have U.S.-style pay. The lack of pay-gap reduction is consistent with our earlier interpretation that pay simply appears to increase for all foreign listed firms in response to an increase in reservation wages.

\subsection{Compensation around CEO Turnover: Test of Agency Arguments}

One plausible interpretation of our results is that entrenched executives engage in U.S. activities to capture the higher pay levels afforded to U.S. executives. As discussed by Rose and Shepard (1997), if such rent-seeking behavior is the primary source of our positive association between compensation and U.S. activities, we would expect to see the sensitivity of our firms' compensation to the scope of U.S. operations shift following the departure of the conflicted executive. We examine the relations between total compensation and U.S. sales ratios, U.S. acquisition ratios, and U.S. listings before and after 80 CEO turnover events in our sample. These estimations (not tabulated) fail to find a shift in the sensitivity of total compensation to these U.S. market interaction variables around the turnover events, consistent with agency conflicts not being the primary driver of the observed association.

\subsection{Effect of geographic proximity}

If the non-U.S. product market exposure is mostly in countries that are closer to the U.K., it would reduce the effort and risk in managing those activities compared to the more distant U.S. resulting in lower pay when foreign exposure is in countries closer to the U.K. To explore this potential explanation for the U.S. interaction results, we examine our earlier results separating geographic sales by proximity to the U.K. While segment disclosure information is not very detailed we are able to identify sales to EU countries which are of closer geographical proximity than other countries. We separate nonU.S. foreign sales into E.U sales and rest of the world sales. In untabulated results we find that the coefficient on U.S. Sales remains statistically significantly associated with compensation and similar to magnitude to the results presented in Table 2 Panel B. In contrast, the coefficients on E.U. sales and the rest of the world sales are not significantly different from zero or from each other implying that geographic distance does not appear to drive our results. Moreover, the coefficient on EU is significantly smaller in magnitude than the one on U.S. 


\section{Conclusions}

We use broad cross-sectional and narrow event-window analyses to provide evidence that the presence of U.S. product market activities is associated with higher pay, greater use of U.S.-style incentive pay, and a reduction in the U.S.-U.K. pay gap. These effects are incremental to U.S. capital market interactions measured as a U.S. exchange listing and to the CEO's personal and professional links to the U.S. The associations are also robust to controls for the scope of the firm's non-U.S. foreign market interactions, as well as firm-level and executive characteristics, such as current firm performance, firm size, and executive age, which have been shown to influence pay in other studies. Additional analyses show that the use of U.S. pay consultants increases the sensitivity of U.K. pay practices to U.S. activities.

The documented associations are consistent with arguments that firms exposed to U.S. market competition have an incentive to adopt U.S. pay practices to alleviate internal and external pay disparities. However, we cannot rule out other mechanisms by which greater U.S. exposure can be associated with greater pay and a greater use of incentive-based pay. For example, U.K. executives wishing to increase their pay could undertake U.S. market activities to force the board to adopt U.S.-style pay arrangements. In that case, the initiation of US activities does not create the incentive per se, but instead, serves as the conduit by which U.K. executives transfer U.S. pay practices to their firm. Similarly, the likelihood of U.S.-based competitors operating in the U.K. market could be correlated with the extent to which the U.K. firm competes in the U.S. product market; the presence of such product market competition in the U.K. could increase pressures to adopt U.S.-style compensation for local managerial talent.

These alternative explanations cannot be refuted with our current research design; as such, our ability to assign causal mechanisms to our documented associations is limited. We acknowledge the likelihood of other mechanisms or paths by which local compensation practices can be influenced through cross-border transactions. Nevertheless, our evidence is relevant. Given our research design, a failure to document an association between U.K. compensation practices and our measures of U.S. market interactions would cast meaningful doubt on arguments that cross-border market interactions influence home-country compensation arrangements. Instead, our evidence is generally consistent with these arguments. As such, the paper contributes to the broader literature on the globalization of governance practices by showing how cross-country economic interactions can produce similarities in compensation practices (Bebchuk and Roe 1999, Hansmann and Kraakman 2001, Khanna et al. 2004). Taken together, our results are consistent with cross-border transactions and foreign market interactions influencing home-country compensation practices, and they provide new evidence on potential market-based channels through which U.S.-style compensation practices can spread worldwide. 


\section{References}

Abowd, J., M. Bognanno. 1995. International differences in executive and managerial compensation. R. Freeman, L. Katz, eds. Differences and Changes in Wage Structures. The University of Chicago Press, Chicago, IL, 67-103.

Baker, G., B. Hall. 2004. CEO incentives and firm size. Journal of Labor Economics 22 767-798.

Bebchuk, L., M. J. Roe. 1999. A theory of path dependence in corporate ownership and governance. Stanford Law Review 52(1) 127-170.

Bizjak, J., M. Lemmon, L. Naveen. 2008. Does the use of peer groups contribute to higher pay and less efficient compensation? Journal of Financial Economics 91 152-168.

Blasko, M., J. Netter, J. Sinkey. 2000. Value creation and the challenges of an international transaction: The DaimlerChrylser merger. International Review of Financial Analysis 9 77-102.

Carter, M. E., C. D. Ittner, S. L. Zechman. 2009a. Explicit relative performance evaluation in performance-vested grants. Review of Accounting Studies 14(2/3) 269-306.

Carter, M. E., L. Lynch, V. Zamora. 2009b. The Americanization of CEO pay in European firms. Working paper, Boston College, Chestnut Hill, MA.

Cheffins, B. 2003. Will executive pay globalize along American lines? Corporate Governance 11(1) 824.

Conyon, M., K. Murphy. 2000. The prince and the pauper: CEO pay in the US and UK. The Economic Journal 110 F640-F671.

Conyon, M., J. Core, W. Guay. 2011. Are US CEOs paid more than UK CEOs? Inferences from riskadjusted pay. Review of Financial Studies 24(2) 402-438.

Conyon, M., N. Fernandes, M. Ferreira, P. Matos, K. Murphy. 2010. The executive compensation controversy: A transatlantic analysis. Working paper.

Core, J., W. Guay. 1999. The use of equity grants to manage optimal equity incentive levels. Journal of Accounting and Economics 28(2) 151-184.

Core, J., W. Guay. 2001. Stock option plans for non-executive employees. Journal of Financial Economics 61(2) 253-287.

Core, J., R. Holthausen, D. Larcker. 1999. Corporate governance, chief executive officer compensation, and firm performance. Journal of Financial Economics 51(3) 371-406.

Faulkender, M., J. Yang. 2010. Inside the black box: The role and composition of peer groups. Journal of Financial Economics 96 257-270.

Fernandes, N., M. Ferreira, P. Matos, K. Murphy. 2011. Are US CEOs paid more? New international evidence. Working paper, ECGI (October). 
Hall, B. J., J. B. Liebman. 1998. Are CEOs really paid like bureaucrats? Quarterly Journal of Economics 113(3) 653-691.

Hansmann, H., R. Kraakman. 2001. The end of history for corporate law. Georgetown Law Journal 89 439-468.

Kaplan, S. 1994a. Top executive rewards and firm performance: A comparison of Japan and the U.S. Journal of Political Economy 102 510-546.

Kaplan, S. 1994b. Top executives, turnover, and firm performance in Germany. Journal of Law, Economics, and Organization 10 142-159.

Khanna, T., K. Palepu, S. Srinivasan. 2004. Disclosure practices of foreign companies interacting with US markets. Journal of Accounting Research 42(2) 475-508.

Pagano, M., A. Roell, J. Zechner. 2002. The geography of equity listing: why do companies list abroad? Journal of Finance 57(6) 2651-2694.

Piotroski, J., S. Srinivasan. 2008. Regulation and bonding: The Sarbanes-Oxley Act and the flow of international listings. Journal of Accounting Research 46(2) 382-425.

Rose, N. L., A. Shepard. 1997. Firm diversification and CEO compensation: Managerial ability or executive entrenchment? RAND Journal of Economics 28(3) 489-514.

Sapp, S. 2008. The impact of corporate governance on executive compensation. European Financial Management 14(4) 710-746.

Sarkissian, S., M. Schill. 2004. The overseas listing decision: New evidence of proximity preference. Review of Financial Studies 17 769-809.

Seetharaman, A., F. Gul, S. Lynn. 2002. Litigation risk and audit fees: evidence from UK firms crosslisted on US markets. Journal of Accounting and Economics 33(1) 91-115.

Smith, C., R. Watts. 1992. The investment opportunity set and corporate financing, dividend, and compensation policies. Journal of Financial Economics 32(3) 263-292.

Southam, C., S. Sapp. 2010. Compensation across executive labor markets: What can we learn from cross-listed firms? Journal of International Business Studies 41(1) 70-87.

Thomas, R. 2008. International executive pay: Current practices and future trends. Working paper, Vanderbilt University Law School, Nashville, TN.

Towers Perrin. 2001. Worldwide Total Remuneration 2001-2002.

Yermack, D. 1996. Higher market valuation of companies with a small board of directors. Journal of Financial Economics 40 185-211. 
Table 1 Descriptive Statistics

This table presents descriptive statistics on our sample of U.K. firm-years over the period 2002-2007. $\mathrm{N}=1,543$

Panel A: Firm and CEO characteristics

\begin{tabular}{|c|c|c|c|c|c|c|c|c|c|}
\hline & Mean & $\begin{array}{l}\text { Std. } \\
\text { Dev. }\end{array}$ & Min & $5 \%$ & $25 \%$ & Median & $75 \%$ & $95 \%$ & Max \\
\hline Assets ( $£$ millions) & 16,672 & 78,180 & 21 & 179 & 586 & 1,348 & 4,518 & 49,961 & 996,023 \\
\hline Ln(Assets) & 14.42 & 1.70 & 9.94 & 12.10 & 13.28 & 14.11 & 15.32 & 17.73 & 20.72 \\
\hline MVE ( $£$ mill.) & 4,895 & 13,582 & 33 & 278 & 5301 & 1,099 & 2,969 & 21,554 & 121,883 \\
\hline Ln(MVE) & 14.17 & 1.34 & 10.40 & 12.54 & 13.18 & 13.91 & 14.90 & 16.89 & 18.62 \\
\hline Market-to-Book & 3.24 & 2.86 & 0.44 & 0.61 & 1.39 & 2.35 & 3.93 & 10.92 & 12.68 \\
\hline ROA & 0.09 & 0.09 & -0.23 & -0.01 & 0.04 & 0.08 & 0.13 & 0.26 & 0.40 \\
\hline CFO & 0.09 & 0.08 & -0.09 & -0.01 & 0.03 & 0.08 & 0.13 & 0.24 & 0.40 \\
\hline Return & 0.08 & 0.23 & -0.49 & -0.26 & -0.05 & 0.06 & 0.19 & 0.49 & 0.93 \\
\hline Volatility & 0.29 & 0.14 & 0.00 & 0.15 & 0.20 & 0.26 & 0.35 & 0.54 & 0.91 \\
\hline Percent Shares Held & 1.38 & 5.27 & 0.00 & 0.00 & 0.01 & 0.05 & 0.25 & 8.48 & 36.24 \\
\hline Ln(Percent Shares Held) & 0.33 & 0.71 & 0.00 & 0.00 & 0.01 & 0.05 & 0.22 & 2.25 & 3.62 \\
\hline Percent Inside Director & 40.99 & 12.11 & 7.69 & 21.43 & 33.33 & 41.67 & 50.00 & 60.00 & 100.00 \\
\hline Board Size & 9.68 & 2.67 & 3.00 & 6.00 & 8.00 & 9.00 & 11.00 & 15.00 & 21.00 \\
\hline Ln(Board Size) & 2.23 & 0.27 & 1.10 & 1.79 & 2.08 & 2.20 & 2.40 & 2.71 & 3.04 \\
\hline CEO Age & 51.87 & 6.83 & 31.00 & 41.00 & 47.00 & 52.00 & 57.00 & 62.00 & 77.00 \\
\hline CEO Tenure (months) & 63.98 & 62.48 & 1.00 & 7.00 & 24.00 & 46.00 & 82.00 & 182.00 & 480.00 \\
\hline Ln(CEO Tenure) & 3.76 & 0.97 & 0.69 & 2.08 & 3.22 & 3.85 & 4.42 & 5.21 & 6.18 \\
\hline
\end{tabular}

Panel B: Foreign, U.S., and non-U.S. foreign market interactions

\begin{tabular}{|c|c|c|c|c|c|c|c|c|c|}
\hline & Mean & $\begin{array}{l}\text { Std. } \\
\text { Dev. }\end{array}$ & Min & $5 \%$ & $25 \%$ & Median & $75 \%$ & $95 \%$ & Max \\
\hline Foreign Sales Ratio & 0.42 & 0.38 & 0.00 & 0.00 & 0.00 & 0.39 & 0.81 & 1.00 & 1.00 \\
\hline U.S. Sales Ratio & 0.15 & 0.20 & 0.00 & 0.00 & 0.00 & 0.00 & 0.28 & 0.56 & 0.99 \\
\hline Non-U.S. Foreign Sales & 0.28 & 0.30 & 0.00 & 0.00 & 0.00 & 0.17 & 0.50 & 0.85 & 1.00 \\
\hline Foreign Acquisitions & 0.54 & 0.50 & 0.00 & 0.00 & 0.00 & 1.00 & 1.00 & 1.00 & 1.00 \\
\hline U.S. Acquisitions & 0.38 & 0.49 & 0.00 & 0.00 & 0.00 & 0.00 & 1.00 & 1.00 & 1.00 \\
\hline Non-U.S. Foreign Acquisitions & 0.50 & 0.50 & 0.00 & 0.00 & 0.00 & 0.00 & 1.00 & 1.00 & 1.00 \\
\hline Ln(Foreign Acquisition Ratio) & 0.13 & 0.23 & 0.00 & 0.00 & 0.00 & 0.00 & 0.16 & 0.59 & 1.56 \\
\hline Ln(U.S. Acquisition Ratio) & 0.07 & 0.18 & 0.00 & 0.00 & 0.00 & 0.00 & 0.03 & 0.39 & 1.55 \\
\hline Ln(Non-U.S. For. Acquis. Ratio) & 0.07 & 0.14 & 0.00 & 0.00 & 0.00 & 0.00 & 0.07 & 0.37 & 0.96 \\
\hline Foreign Listing & 0.29 & 0.45 & 0.00 & 0.00 & 0.00 & 0.00 & 1.00 & 1.00 & 1.00 \\
\hline U.S. Listing & 0.26 & 0.44 & 0.00 & 0.00 & 0.00 & 0.00 & 1.00 & 1.00 & 1.00 \\
\hline Non-U.S. Foreign Listing & 0.07 & 0.25 & 0.00 & 0.00 & 0.00 & 0.00 & 0.00 & 1.00 & 1.00 \\
\hline CEO Foreign Education & 0.49 & 0.50 & 0.00 & 0.00 & 0.00 & 0.00 & 1.00 & 1.00 & 1.00 \\
\hline CEO U.S. Education & 0.45 & 0.50 & 0.00 & 0.00 & 0.00 & 0.00 & 1.00 & 1.00 & 1.00 \\
\hline CEO Non-U.S. Foreign Educ. & 0.15 & 0.36 & 0.00 & 0.00 & 0.00 & 0.00 & 0.00 & 1.00 & 1.00 \\
\hline CEO Foreign Board Experience & 0.09 & 0.28 & 0.00 & 0.00 & 0.00 & 0.00 & 0.00 & 1.00 & 1.00 \\
\hline CEO U.S. Board Experience & 0.04 & 0.21 & 0.00 & 0.00 & 0.00 & 0.00 & 0.00 & 0.00 & 1.00 \\
\hline CEO Non-U.S. Foreign Board & 0.04 & 0.21 & 0.00 & 0.00 & 0.00 & 0.00 & 0.00 & 0.00 & 1.00 \\
\hline CEO Foreign Nationality & 0.18 & 0.38 & 0.00 & 0.00 & 0.00 & 0.00 & 0.00 & 1.00 & 1.00 \\
\hline CEO U.S. Nationality & 0.06 & 0.23 & 0.00 & 0.00 & 0.00 & 0.00 & 0.00 & 1.00 & 1.00 \\
\hline CEO Non-U.S. For. Nationality & 0.12 & 0.33 & 0.00 & 0.00 & 0.00 & 0.00 & 0.00 & 1.00 & 1.00 \\
\hline
\end{tabular}


Table 1 (continued) Descriptive Statistics

Panel C: Compensation variables (in $£$ s thousand)

\begin{tabular}{|c|c|c|c|c|c|c|c|c|c|}
\hline & Mean & $\begin{array}{l}\text { Std. } \\
\text { Dev. }\end{array}$ & Min & $5 \%$ & $25 \%$ & Median & $75 \%$ & $95 \%$ & Max \\
\hline Total Compensation & $1,511.73$ & $1,897.92$ & 14.74 & 321.00 & 621.00 & 971.32 & $1,696.45$ & $4,2833.38$ & $27,021.01$ \\
\hline Ln(Total Compensation) & 13.86 & 0.82 & 9.60 & 12.68 & 13.34 & 13.79 & 14.34 & 15.27 & 17.11 \\
\hline Cash Compensation & 921.80 & 714.55 & 0.00 & 269.28 & 501.00 & 714.00 & $1,097.00$ & $2,357.66$ & $7,613.00$ \\
\hline Ln(Cash Compensation) & 13.46 & 1.08 & 0.00 & 12.50 & 13.12 & 13.48 & 13.91 & 14.67 & 15.85 \\
\hline Salary & 469.24 & 237.44 & 0.00 & 190.00 & 315.00 & 420.00 & 586.00 & 888.00 & $2,761.32$ \\
\hline Ln(Salary) & 12.88 & 1.07 & 0.00 & 12.15 & 12.66 & 12.95 & 13.28 & 13.70 & 14.83 \\
\hline Bonus & 406.17 & 560.43 & 0.00 & 0.00 & 109.20 & 253.92 & 480.00 & $1,424.00$ & $7,127.00$ \\
\hline Ln(Bonus) & 11.01 & 4.25 & 0.00 & 0.00 & 11.60 & 12.44 & 13.08 & 14.17 & 15.78 \\
\hline Equity Compensation & 589.94 & $1,559.98$ & 0.00 & 0.00 & 0.00 & 200.00 & 594.23 & $2,143.59$ & $24,924.01$ \\
\hline Ln(Equity Compensation) & 8.63 & 6.16 & 0.00 & 0.00 & 0.00 & 12.21 & 13.30 & 14.58 & 17.03 \\
\hline Option Grant & 0.39 & 0.49 & 0.00 & 0.00 & 0.00 & 0.00 & 1.00 & 1.00 & 1.00 \\
\hline Equity Ratio & 0.25 & 0.24 & 0.00 & 0.00 & 0.00 & 0.23 & 0.42 & 0.65 & 1.00 \\
\hline
\end{tabular}

Panel D: Mean compensation levels conditional on U.S. market exposure

\begin{tabular}{|c|c|c|c|c|c|c|}
\hline & $\begin{array}{l}\text { Total } \\
\text { Compensation } \\
\text { (in } £ s)\end{array}$ & $\begin{array}{l}\text { Cash } \\
\text { Compensation } \\
\text { (in } £ s)\end{array}$ & $\begin{array}{l}\text { Equity } \\
\text { Compensation } \\
\text { (in } £ s \text { ) }\end{array}$ & $\begin{array}{l}\text { Equity } \\
\text { Ratio }\end{array}$ & $\begin{array}{l}\text { Option } \\
\text { Grants }\end{array}$ & $\mathrm{N}$ \\
\hline U.S. Sales & $1,825,071^{* * *}$ & $1,083,569 * * *$ & $741,502 * * *$ & $0.271^{* * *}$ & $0.464 * * *$ & 756 \\
\hline No U.S. Sales & $1,210,738$ & 766,396 & 444,342 & 0.228 & 0.318 & 787 \\
\hline U.S. Acquisitions & $1,928,837 * * *$ & $1,124,276^{* * *}$ & $804,561 * * *$ & $0.286 * * *$ & $0.485^{* * *}$ & 592 \\
\hline No U.S. Acquisitions & $1,252,086$ & 795,753 & 456,333 & 0.226 & 0.332 & 951 \\
\hline U.S. Exchange Listing & $2,567,688^{* * *}$ & $1,382,714^{* * *}$ & $1,184,974 * * *$ & $0.307 * * *$ & $0.454^{* * *}$ & 403 \\
\hline No U.S. Exchange Listing & $1,138,444$ & 758,858 & 379,586 & 0.228 & 0.367 & 1,140 \\
\hline CEO U.S. Education & $1,736,367 * * *$ & $1,033,783 * * *$ & $702,584 * *$ & $0.264 * *$ & 0.404 & 695 \\
\hline CEO No U.S. Education & $1,327,629$ & 830,016 & 497,614 & 0.237 & 0.377 & 848 \\
\hline CEO U.S. Board Exper. & $3,299,679 * * *$ & $1,687,478^{* * *}$ & $1,612,200 * * *$ & $0.325 * * *$ & 0.464 & 69 \\
\hline CEO No U.S. Board Exper. & $1,428,037$ & 885,954 & 542,083 & 0.245 & 0.386 & 1,474 \\
\hline CEO U.S. Nationality & $2,173,275^{* * *}$ & $1,293,850 * * *$ & $879,425 *$ & 0.280 & 0.456 & 90 \\
\hline CEO Non-U.S. Nationality & $1,470,757$ & 898,751 & 572,006 & 0.247 & 0.385 & 1,453 \\
\hline \multicolumn{7}{|c|}{$\begin{array}{l}* * *, * *, * \text { U.S. realization significantly different from No U.S. activity realization at the one percent, five percent, and ten percent levels (two- } \\
\text { tailed test) respectively. }\end{array}$} \\
\hline \multicolumn{7}{|c|}{ Variable Definitions (Firm and CEO Characteristics): } \\
\hline Assets & \multicolumn{6}{|c|}{ Total assets in thousands of pounds sterling at the end of year $t$. } \\
\hline Ln(Assets) & \multicolumn{6}{|c|}{ Natural logarithm of total assets in thousands of pounds sterling at the end of year $t$. } \\
\hline MVE & \multirow{2}{*}{\multicolumn{6}{|c|}{$\begin{array}{l}\text { Number of shares outstanding in thousands times the firm's share price in pounds sterling at the end of year } t \text {. } \\
\text { Natural logarithm of the number of shares outstanding in thousands times the firm's share price in pounds } \\
\text { sterling at the end of year } t \text {. }\end{array}$}} \\
\hline $\operatorname{Ln}(M V E)$ & & & & & & \\
\hline Market-to-Book & \multicolumn{6}{|c|}{ Ratio of the market value of equity to the book value of equity at the end of year $t$. } \\
\hline ROA & \multicolumn{6}{|c|}{ Ratio of earnings before interest and taxes to total assets for year $t$. } \\
\hline $\mathrm{CFO}$ & \multicolumn{6}{|c|}{ Ratio of cash flow from operations to total assets for year $t$. } \\
\hline Stock Return & \multicolumn{6}{|c|}{ Annual return including dividends on the firm’s common stock for year $t$. } \\
\hline Return Volatility & \multicolumn{6}{|c|}{ Annualized volatility of daily returns on the firm’s common stock for year $t$. } \\
\hline Percent Shares Held & \multicolumn{6}{|c|}{ Percent of the firm's shares outstanding held by the CEO in the form of unrestricted shares at the end of year $t$. } \\
\hline Ln(Percent Shares Held) & \multicolumn{6}{|c|}{$\begin{array}{l}\text { Natural logarithm of one plus the ratio of the firm's shares outstanding held by the CEO in the form of } \\
\text { unrestricted shares at the end of year } t \text { to total shares outstanding at the end of year } t \text {. }\end{array}$} \\
\hline Percent Inside Director & \multicolumn{6}{|c|}{ Percentage of directors serving on the board who are insiders in year $t$. } \\
\hline Board Size & \multicolumn{6}{|c|}{ Number of directors serving on the board in year $t$. } \\
\hline Ln(Board Size) & \multicolumn{6}{|c|}{ Natural logarithm of the number of directors serving on the board in year $t$. } \\
\hline CEO Age & \multicolumn{6}{|c|}{ Age of the CEO at the end of year $t$. } \\
\hline CEO Tenure & \multicolumn{6}{|c|}{ The number of months that the CEO has been in office at the end of year $t$. } \\
\hline Ln(CEO Tenure) & \multicolumn{6}{|c|}{ Natural logarithm of the number of months that the CEO has been in office at the end of year $t$. } \\
\hline
\end{tabular}


Table 2 Influence of Firm-Level Foreign Market Interactions on U.K. Compensation Practices

This table presents select coefficients from various pooled, cross-sectional estimations of Equation 2. The dependent variable, Ln(Total Compensation), equals the natural logarithm of the total annual compensation earned by the CEO of firm $i$ in year $t$. In panel B, each of the firm's foreign market variables is replaced with the firm's U.S. and non-U.S. foreign analogues. All models are estimated using ordinary least squares. Standard errors (in parentheses) are clustered at the firm level. $\mathrm{N}=1,543$

Panel A: Foreign market interactions

\begin{tabular}{|c|c|c|c|c|}
\hline Foreign Market Interaction: & Sales & Acquisition & Listing & $\begin{array}{c}\text { All Market } \\
\text { Interactions }\end{array}$ \\
\hline Ln(Assets) & $\begin{array}{l}0.318^{* * * *} \\
(0.023)\end{array}$ & $\begin{array}{l}0.331^{* * *} \\
(0.023)\end{array}$ & $\begin{array}{c}0.297^{* * *} \\
(0.026)\end{array}$ & $\begin{array}{l}0.290^{* * * *} \\
(0.025)\end{array}$ \\
\hline Market-to-Book & $\begin{array}{l}0.017^{* *} \\
(0.008)\end{array}$ & $\begin{array}{l}0.018^{* *} \\
(0.008)\end{array}$ & $\begin{array}{l}0.018^{* * *} \\
(0.008)\end{array}$ & $\begin{array}{l}0.016^{* *} \\
(0.008)\end{array}$ \\
\hline ROA & $\begin{array}{c}0.620^{*} \\
(0.319)\end{array}$ & $\begin{array}{c}0.595^{*} \\
(0.323)\end{array}$ & $\begin{array}{c}0.527^{*} \\
(0.314)\end{array}$ & $\begin{array}{l}0.558^{*} \\
(0.314)\end{array}$ \\
\hline CFO & $\begin{array}{c}0.618 \\
(0.398)\end{array}$ & $\begin{array}{l}0.734^{*} \\
(0.405)\end{array}$ & $\begin{array}{c}0.621 \\
(0.398)\end{array}$ & $\begin{array}{c}0.536 \\
(0.393)\end{array}$ \\
\hline Stock Return & $\begin{array}{l}0.143^{*} \\
(0.078)\end{array}$ & $\begin{array}{l}0.158^{* *} \\
(0.077)\end{array}$ & $\begin{array}{l}0.153^{* *} \\
(0.076)\end{array}$ & $\begin{array}{l}0.143^{*} \\
(0.077)\end{array}$ \\
\hline Return Volatility & $\begin{array}{c}0.215 \\
(0.201)\end{array}$ & $\begin{array}{c}0.318 \\
(0.205)\end{array}$ & $\begin{array}{c}0.305 \\
(0.198)\end{array}$ & $\begin{array}{c}0.229 \\
(0.197)\end{array}$ \\
\hline Ln(Tenure) & $\begin{array}{l}0.089^{* * * *} \\
(0.024)\end{array}$ & $\begin{array}{l}0.089^{* * * *} \\
(0.025)\end{array}$ & $\begin{array}{l}0.085^{* * * *} \\
(0.024)\end{array}$ & $\begin{array}{l}0.086^{* * * *} \\
(0.024)\end{array}$ \\
\hline Ln(Percent Shares Held) & $\begin{array}{l}-0.066 \\
(0.041)\end{array}$ & $\begin{array}{c}-0.056 \\
(0.041)\end{array}$ & $\begin{array}{l}-0.051 \\
(0.040)\end{array}$ & $\begin{array}{l}-0.060 \\
(0.040)\end{array}$ \\
\hline Percent Inside Directors & $\begin{array}{c}-0.008^{* * * *} \\
(0.002)\end{array}$ & $\begin{array}{c}-0.008^{* * * *} \\
(0.002)\end{array}$ & $\begin{array}{c}-0.008^{* * * *} \\
(0.002)\end{array}$ & $\begin{array}{c}-0.008^{* * * *} \\
(0.002)\end{array}$ \\
\hline Ln(Board Size) & $\begin{array}{l}0.203^{*} \\
(0.119)\end{array}$ & $\begin{array}{l}0.233^{* *} \\
(0.118)\end{array}$ & $\begin{array}{l}0.210^{*} \\
(0.117)\end{array}$ & $\begin{array}{c}0.182 \\
(0.119)\end{array}$ \\
\hline Foreign Sales Ratio & $\begin{array}{l}0.281^{* * * *} \\
(0.086)\end{array}$ & & & $\begin{array}{l}0.228^{* *} \\
(0.090)\end{array}$ \\
\hline Ln(Foreign Acquisition Ratio) & & $\begin{array}{c}0.157 \\
(0.097)\end{array}$ & & $\begin{array}{c}0.013 \\
(0.091)\end{array}$ \\
\hline Foreign Listing & & & $\begin{array}{l}0.249^{* * *} \\
(0.070)\end{array}$ & $\begin{array}{l}0.213^{* * * *} \\
(0.074)\end{array}$ \\
\hline Intercept \& Fixed Effects & Included & Included & Included & Included \\
\hline Adjusted R-Squared & 0.458 & 0.450 & 0.460 & 0.465 \\
\hline
\end{tabular}

Panel B: U.S. and non-U.S. foreign market interactions

\begin{tabular}{|c|c|c|c|c|}
\hline Foreign Market Interaction: & Sales & Acquisition & Listing & $\begin{array}{l}\text { All Market } \\
\text { Interactions }\end{array}$ \\
\hline U.S. Sales Ratio & $\begin{array}{l}0.624^{* * * *} \\
(0.129)\end{array}$ & & & $\begin{array}{c}0.594 * * * \\
(0.143)\end{array}$ \\
\hline Non-U.S. Foreign Sales Ratio & $\begin{array}{c}0.101 \\
(0.111)\end{array}$ & & & $\begin{array}{c}0.077 \\
(0.112)\end{array}$ \\
\hline Ln(U.S. Acquisition Ratio) & & $\begin{array}{c}0.188 \\
(0.114)\end{array}$ & & $\begin{array}{l}-0.138 \\
(0.095)\end{array}$ \\
\hline Ln(Non-U.S. For. Acq. Ratio) & & $\begin{array}{c}0.089 \\
(0.159)\end{array}$ & & $\begin{array}{c}0.082 \\
(0.136)\end{array}$ \\
\hline U.S. Listing & & & $\begin{array}{c}0.232^{* * * *} \\
(0.070)\end{array}$ & $\begin{array}{c}0.170 * * \\
(0.071)\end{array}$ \\
\hline Non-U.S. Foreign Listing & & & $\begin{array}{l}0.204^{*} \\
(0.109)\end{array}$ & $\begin{array}{c}0.174 \\
(0.111)\end{array}$ \\
\hline U.S. = Non-U.S. Sales p-value & 0.001 & & & 0.004 \\
\hline U.S. = Non-U.S. Acquis. p-value & & 0.603 & & 0.162 \\
\hline U.S. = Non-U.S. Listing p-value & & & 0.826 & 0.972 \\
\hline Control Variables \& Fixed Effects & Included & Included & Included & Included \\
\hline Adjusted R-Squared & 0.465 & 0.450 & 0.460 & 0.471 \\
\hline
\end{tabular}

$* * *, * *, *$ Significantly different from zero at the one, five, and ten percent levels (two-tailed test) respectively, using standard errors clustered by firm. 


\section{Table 3 Influence of Firm-Level U.S. and Non-U.S. Foreign Market Interactions on the Components of U.K. Executive Compensation Packages}

This table presents select coefficients from various pooled, cross-sectional estimations of the following models:

$$
\begin{aligned}
& \left.\operatorname{Ln}(\text { Compensation })_{\mathrm{it}}=\alpha+\sum_{\mathrm{k}=1}^{\mathrm{n}} \gamma_{\mathrm{k}} \text { Industry }_{\mathrm{k}}+\sum_{\mathrm{t}=1}^{4} \text { Year }_{\mathrm{t}}+\beta_{1} \text { Ln( } \text { Assets }_{i t}\right)+\beta_{2} \text { Market-to-Book }_{i t}+\beta_{3} R O A_{i t}+\beta_{4} C_{\text {CFO }} \\
& +\beta_{5} \text { Stock Return }_{i t}+\beta_{6} \text { Return Volatility }_{i t}+\beta_{7} \text { Ln }\left(\text { Tenure }_{i t}\right)+\beta_{8} \operatorname{Ln}\left(\text { Percent Shares Held }_{i t}\right)+\beta_{9} \text { Percent Inside Directors }_{i t} \\
& \left.\left.+\beta_{10} \text { Ln(Board Size }{ }_{i t}\right)+\beta_{11} \text { U.S. Sales Ratio }{ }_{i t}+\beta_{12} \text { Non-U.S. Foreign Sales Ratio }{ }_{i t}+\beta_{13} \text { Ln(U.S. Acquisition Ratio }\right)_{i t} \\
& +\beta_{14} L n(\text { Non-U.S. Foreign Acquisition Ratio })_{i t}+\beta_{15} \text { U.S. Listing }{ }_{i t}+\beta_{16} \text { Non-U.S. Foreign Listing }{ }_{i t}+\varepsilon_{i t}
\end{aligned}
$$

U.S. Activity and Non-U.S. Foreign Activity equal the specified measure of firm i's U.S. and Non-U.S. foreign market interactions in year $t$. All Cash Compensation models are estimated using ordinary least squares. All Ln(Equity Compensation) and Equity

\begin{tabular}{|c|c|c|c|c|c|c|}
\hline \multirow[b]{2}{*}{ Dependent Variable: } & \multicolumn{3}{|c|}{ Cash Compensation } & \multicolumn{3}{|c|}{ Equity Compensation } \\
\hline & $\begin{array}{c}\text { Ln(Cash } \\
\text { Comp.) }\end{array}$ & Ln(Salary) & Ln(Bonus) & $\begin{array}{c}\text { Ln(Equity } \\
\text { Comp.) }\end{array}$ & $\begin{array}{c}\text { Equity } \\
\text { Ratio }\end{array}$ & $\begin{array}{c}\text { Option } \\
\text { Grant }\end{array}$ \\
\hline U.S. Sales Ratio & $\begin{array}{l}0.537^{* * *} \\
(0.134)\end{array}$ & $\begin{array}{l}0.335^{* *} \\
(0.141)\end{array}$ & $\begin{array}{c}1.161^{*} \\
(0.695)\end{array}$ & $\begin{array}{c}2.584 \\
(2.079)\end{array}$ & $\begin{array}{c}0.102 \\
(0.076)\end{array}$ & $\begin{array}{l}1.226^{* *} \\
(0.543)\end{array}$ \\
\hline Non-U.S. Foreign Sales Ratio & $\begin{array}{c}0.210^{*} \\
(0.121)\end{array}$ & $\begin{array}{c}0.092 \\
(0.099)\end{array}$ & $\begin{array}{l}-0.520 \\
(0.658)\end{array}$ & $\begin{array}{c}0.469 \\
(1.339)\end{array}$ & $\begin{array}{c}-0.029 \\
(0.048)\end{array}$ & $\begin{array}{c}0.595 \\
(0.371)\end{array}$ \\
\hline Ln(U.S. Acquisition Ratio) & $\begin{array}{c}-0.503 \\
(0.420)\end{array}$ & $\begin{array}{c}-0.470 \\
(0.396)\end{array}$ & $\begin{array}{l}-0.276 \\
(0.660)\end{array}$ & $\begin{array}{c}0.792 \\
(1.532)\end{array}$ & $\begin{array}{c}0.024 \\
(0.073)\end{array}$ & $\begin{array}{c}0.847^{*} \\
(0.456)\end{array}$ \\
\hline Ln(Non-U.S. For. Acq. Ratio) & $\begin{array}{c}0.103 \\
(0.154)\end{array}$ & $\begin{array}{c}0.069 \\
(0.249)\end{array}$ & $\begin{array}{c}-1.143 \\
(0.951)\end{array}$ & $\begin{array}{c}0.700 \\
(2.413)\end{array}$ & $\begin{array}{c}0.026 \\
(0.083)\end{array}$ & $\begin{array}{c}-0.475 \\
(0.640)\end{array}$ \\
\hline U.S. Listing & $\begin{array}{l}0.192^{* * *} \\
(0.072)\end{array}$ & $\begin{array}{c}0.123^{*} \\
(0.069)\end{array}$ & $\begin{array}{c}0.184 \\
(0.378)\end{array}$ & $\begin{array}{c}-0.662 \\
(0.866)\end{array}$ & $\begin{array}{c}-0.006 \\
(0.033)\end{array}$ & $\begin{array}{c}-0.097 \\
(0.244)\end{array}$ \\
\hline Non-U.S. Foreign Listing & $\begin{array}{c}0.170^{*} \\
(0.093)\end{array}$ & $\begin{array}{c}0.050 \\
(0.079)\end{array}$ & $\begin{array}{c}0.817 \\
(0.589)\end{array}$ & $\begin{array}{c}-0.118 \\
(1.047)\end{array}$ & $\begin{array}{c}0.016 \\
(0.043)\end{array}$ & $\begin{array}{c}-0.401 \\
(0.333)\end{array}$ \\
\hline U.S. = Non-U.S. Sales p-value & 0.032 & 0.074 & 0.044 & 0.195 & 0.072 & 0.177 \\
\hline U.S. = Non-U.S. Acquis. p-value & 0.113 & 0.147 & 0.237 & 0.974 & 0.984 & 0.056 \\
\hline U.S. = Non-U.S. Listing p-value & 0.838 & 0.239 & 0.193 & 0.685 & 0.700 & 0.218 \\
\hline Controls \& Fixed Effects & Included & Included & Included & Included & Included & Included \\
\hline Adjusted R-Squared & 0.253 & 0.157 & 0.120 & 0.030 & 0.162 & 0.121 \\
\hline
\end{tabular}
Ratio models are estimated using Tobit. The Option Grant model is estimated using logit. Standard errors (in parentheses) are clustered at the firm level. P-values on the equality of the U.S. Activity and Non-U.S. Foreign Activity coefficients are from a ttest (one-sided). $\mathrm{N}=1,543$

***, **, * Significantly different from zero at the one, five, and ten percent levels (two-tailed test) respectively, using standard errors clustered by firm. 
Table 4 Practices

\section{Influence of CEO-Level Foreign Market Characteristics on U.K. Compensation}

$$
\begin{aligned}
& \left.\operatorname{Ln}\left(\text { Total Compensation }_{\mathrm{it}}\right)=\alpha+\sum_{\mathrm{k}=1}^{\mathrm{n}} \gamma_{\mathrm{k}} \text { Industry }_{\mathrm{k}}+\sum_{\mathrm{t}=1}^{4} \text { Year }_{\mathrm{t}}+\beta_{1} \text { Ln }_{\text {(Assets }}\right)+\beta_{2} \text { Market-to-Book }_{i t}+\beta_{3} \text { ROA }_{i t}+\beta_{4} \text { CFO }_{i t}+\beta_{5} \text { Stock } \\
& \text { Return }_{i t}+\beta_{6} \text { Return Volatility }_{i t}+\beta_{7} \operatorname{Ln}\left(\text { Tenure }_{i t}\right)+\beta_{8} \operatorname{Ln}\left(\text { Percent Shares Held }_{i t}\right)+\beta_{9} \text { Percent Inside Directors }_{i t} \\
& \left.+\beta_{10} \operatorname{Ln}\left(\text { Board Size }_{i t}\right)+\beta_{11} \text { U.S. Sales Ratio }{ }_{i t}+\beta_{14} \text { Non-U.S. Foreign Sales Ratio }{ }_{i t}+\beta_{12} \text { Ln(U.S. Acquisition Ratio }\right)_{i t} \\
& \left.+\beta_{15} \text { Ln(Non-U.S. Foreign Acquisition Ratio }\right)_{i t}+\beta_{13} \text { U.S. Listing }{ }_{i t}+\beta_{16} \text { Non-U.S. Foreign Listing }{ }_{i t}+\beta_{18} \text { CEO U.S. Education }{ }_{i t} \\
& +\beta_{21} C E O \text { non-U.S. Foreign Education }{ }_{i t}+\beta_{17} C E O \text { U.S. Nationality }{ }_{i t}+\beta_{20} C E O \text { non-U.S. Foreign Nationality }{ }_{i t} \\
& +\beta_{19} \text { CEO U.S. Board Experience } e_{i t}+\beta_{22} \text { CEO non-U.S. Foreign Board Experience } e_{i t}+\varepsilon_{i \mathrm{it}}
\end{aligned}
$$

\begin{tabular}{|c|c|c|c|c|c|}
\hline & $\begin{array}{c}\text { CEO } \\
\text { Education }\end{array}$ & $\begin{array}{c}\text { CEO } \\
\text { Nationality }\end{array}$ & $\begin{array}{l}\text { CEO Board } \\
\text { Experience }\end{array}$ & $\begin{array}{c}\text { All CEO } \\
\text { Characteristics }\end{array}$ & $\begin{array}{l}\text { All Market } \\
\text { Interactions }\end{array}$ \\
\hline CEO U.S. Education & $\begin{array}{c}0.023 \\
(0.054)\end{array}$ & & & $\begin{array}{c}0.010 \\
(0.053)\end{array}$ & $\begin{array}{l}-0.023 \\
(0.052)\end{array}$ \\
\hline CEO Non-U.S. Foreign Education & $\begin{array}{l}-0.043 \\
(0.077)\end{array}$ & & & $\begin{array}{l}-0.035 \\
(0.078)\end{array}$ & $\begin{array}{l}-0.034 \\
(0.079)\end{array}$ \\
\hline CEO U.S. Nationality & & $\begin{array}{c}0.194^{*} \\
(0.110)\end{array}$ & & $\begin{array}{c}0.157 \\
(0.110)\end{array}$ & $\begin{array}{c}0.076 \\
(0.099)\end{array}$ \\
\hline CEO Non-U.S. Foreign Nationality & & $\begin{array}{l}-0.075 \\
(0.084)\end{array}$ & & $\begin{array}{l}-0.074 \\
(0.090)\end{array}$ & $\begin{array}{l}-0.088 \\
(0.082)\end{array}$ \\
\hline CEO U.S. Board Experience & & & $\begin{array}{l}0.233^{* *} \\
(0.108)\end{array}$ & $\begin{array}{l}0.192^{*} \\
(0.102)\end{array}$ & $\begin{array}{l}0.173^{*} \\
(0.091)\end{array}$ \\
\hline CEO Non-U.S. Foreign Board Exper. & & & $\begin{array}{l}0.291^{* *} \\
(0.114)\end{array}$ & $\begin{array}{l}0.302^{* * * *} \\
(0.114)\end{array}$ & $\begin{array}{l}0.248^{* *} \\
(0.108)\end{array}$ \\
\hline U.S. Sales Ratio & & & & & $\begin{array}{l}0.537^{* * *} \\
(0.142)\end{array}$ \\
\hline Non-U.S. Foreign Sales Ratio & & & & & $\begin{array}{c}0.107 \\
(0.111)\end{array}$ \\
\hline Ln(U.S. Acquisition Ratio) & & & & & $\begin{array}{l}-0.126 \\
(0.096)\end{array}$ \\
\hline Ln(Non-U.S. For. Acquisition Ratio) & & & & & $\begin{array}{c}0.136 \\
(0.141)\end{array}$ \\
\hline U.S. Listing & & & & & $\begin{array}{l}0.156^{* *} \\
(0.072)\end{array}$ \\
\hline Non-U.S. Foreign Listing & & & & & $\begin{array}{c}0.173 \\
(0.116)\end{array}$ \\
\hline $\begin{array}{l}\text { U.S. }=\text { Non-U.S. Sales p-value } \\
\text { U.S. }=\text { Non-U.S. Acquis. p-value } \\
\text { U.S. }=\text { Non-U.S. Listing p-value }\end{array}$ & & & & - & $\begin{array}{l}0.014 \\
0.109 \\
0.896\end{array}$ \\
\hline Control Variables \& Fixed Effects & Included & Included & Included & Included & Included \\
\hline Adjusted R-Squared & 0.449 & 0.452 & 0.456 & 0.458 & 0.476 \\
\hline
\end{tabular}

The dependent variable, Ln(Total Compensation), equals the natural logarithm of the total annual compensation earned by the CEO of firm $i$ in year $t$. All models are estimated using ordinary least squares. Standard errors (in parentheses) are clustered at the firm level. P-values on the equality of the U.S. and Non-U.S. foreign variables' coefficients are from a t-test (one-sided). $\mathrm{N}=1,543$

$* * *, * *, *$ Significantly different from zero at the one, five, and ten percent levels (two-tailed test) respectively, using standard errors clustered by firm. 


\section{Table 5 Evidence on Channels that Align U.S.-U.K. Compensation Practices}

This table presents select coefficients from various pooled, cross-sectional estimations of the following model:

$$
\left.\operatorname{Ln}\left(\text { Total Compensation }_{\mathrm{it}}\right)=\alpha+\sum_{\mathrm{k}=1}^{\mathrm{n}} \gamma_{\mathrm{k}} \text { Industry }_{\mathrm{k}}+\sum_{\mathrm{t}=1}^{4} \text { Year }_{\mathrm{t}}+\beta_{1} \text { Ln }_{\text {Assets }}\right)+\beta_{2} \text { Market-to-Book }_{i t}+\beta_{3} \text { ROA }_{i t}+\beta_{4} \text { CFO }_{i t}+\beta_{5} \text { Stock Return }_{i t}
$$

$+\beta_{6}$ Return Volatility $_{i t}+\beta_{7} \operatorname{Ln}\left(\right.$ Tenure $\left._{i t}\right)+\beta_{8} \operatorname{Ln}\left(\right.$ Percent Shares Held $\left._{i t}\right)+\beta_{9}$ Percent Inside Directors $_{i t}+\beta_{10}$ Ln $_{\left(\text {Board Size }_{i t}\right)+\beta_{11} \text { U.S. Sales Ratio } i t}$

$+\beta_{12}$ Non-U.S. Foreign Sales Ratio ${ }_{i t}+\beta_{13} L n(U . S . \text { Acquisition Ratio })_{i t}+\beta_{14} L n(\text { Non-U.S. Foreign Acquisition Ratio })_{i t}+\beta_{15}$ U.S. Listing ${ }_{i t}+\beta_{16}$ Non-

U.S. Foreign Listing ${ }_{i t}+\beta_{17}$ U.S. Channel ${ }_{i t}+\beta_{18}$ Non-U.S. Foreign Channel ${ }_{i t}+\beta_{19}$ U.S. Sales Ratio ${ }_{i t}{ }^{*}$ U.S. Channel ${ }_{i t}+\beta_{20}$ Non-U.S. Foreign Sales

Ratio $_{i t}{ }^{*}$ Non-U.S. Foreign Channel ${ }_{i t}+\beta_{21}$ Ln(U.S. Acquisition Ratio $)_{i t}{ }^{*}$ U.S. Channel ${ }_{i t}+\beta_{22}$ Ln(Non-U.S. Foreign Acquisition Ratio $)_{i t}{ }^{*}$ Non-U.S.

Foreign Channel $_{i t}+\beta_{23}$ U.S. Listing ${ }_{i t} * U S$ Channel $_{i t}+\beta_{24}$ Non-U.S. Foreign Listing ${ }_{i t}{ }^{*}$ Non-U.S. Foreign Channel ${ }_{i t}+\varepsilon_{i t}$

The dependent variable, Ln(Total Compensation), equals the natural logarithm of the total annual compensation earned by the CEO of firm $i$ in year t. U.S. Channel and Non-U.S. Foreign Channel are indicator variables equal to one if the firm uses or is associated with one of four different attributes: Use of a U.S. or non-U.S. foreign compensation consultant, use of a U.S. or nonU.S. foreign peer, the presence of U.S. or non-U.S. foreign board experience among the firm's board of directors, the presence of U.S. or non-U.S. foreign institutional shareholders. All models are estimated using ordinary least squares. Standard errors (in parentheses) are clustered at the firm level. $\mathrm{N}=1,543$

Panel A: Descriptive evidence

\begin{tabular}{|c|c|c|c|c|}
\hline & $\begin{array}{c}\text { Compensation } \\
\text { Consultants }\end{array}$ & $\begin{array}{c}\text { Board } \\
\text { Background } \\
\end{array}$ & $\begin{array}{l}\text { Institutional } \\
\text { Investors }\end{array}$ & $\begin{array}{l}\text { Peer } \\
\text { Group } \\
\end{array}$ \\
\hline All Foreign Activity & 0.507 & 0.520 & 0.131 & 0.150 \\
\hline U.S. Activity & 0.483 & 0.330 & 0.083 & 0.127 \\
\hline Non-U.S. Foreign Activity & 0.024 & 0.420 & 0.048 & 0.112 \\
\hline
\end{tabular}

Panel B: Multivariate analysis

\begin{tabular}{|c|c|c|c|c|c|c|c|c|}
\hline U.S. and Non-U.S. Channel: & $\begin{array}{r}\text { Comp } \\
\text { Con } \\
\end{array}$ & $\begin{array}{l}\text { sation } \\
\text { tants }\end{array}$ & $\begin{array}{r}\mathrm{B} \\
\mathrm{Bacl} \\
\end{array}$ & $\begin{array}{l}\text { rd } \\
\text { ound }\end{array}$ & $\begin{array}{r}\text { Insti } \\
\text { Inv }\end{array}$ & $\begin{array}{l}\text { ional } \\
\text { ors }\end{array}$ & & \\
\hline U.S. Sales Ratio & $\begin{array}{r}0.587^{* * *} \\
(0.138)\end{array}$ & $\begin{array}{c}0.330^{*} \\
(0.187)\end{array}$ & $\begin{array}{c}0.570^{* * * *} \\
(0.134)\end{array}$ & $\begin{array}{c}0.570^{* * * *} \\
(0.160)\end{array}$ & $\begin{array}{l}0.593^{* * *} \\
(0.140)\end{array}$ & $\begin{array}{c}0.737^{* * *} \\
(0.171)\end{array}$ & $\begin{array}{c}0.539^{* * *} \\
(0.139)\end{array}$ & $\begin{array}{c}0.510^{* * *} \\
(0.151)\end{array}$ \\
\hline Non-U.S. Foreign Sales Ratio & $\begin{array}{c}0.016 \\
(0.107)\end{array}$ & $\begin{array}{c}0.032 \\
(0.107)\end{array}$ & $\begin{array}{c}0.022 \\
(0.108)\end{array}$ & $\begin{array}{l}-0.080 \\
(0.131)\end{array}$ & $\begin{array}{c}0.017 \\
(0.107)\end{array}$ & $\begin{array}{l}-0.004 \\
(0.121)\end{array}$ & $\begin{array}{c}0.029 \\
(0.106)\end{array}$ & $\begin{array}{c}0.027 \\
(0.115)\end{array}$ \\
\hline Ln(U.S. Acquisition Ratio) & $\begin{array}{l}-0.143 \\
(0.096)\end{array}$ & $\begin{array}{l}-0.035 \\
(0.174)\end{array}$ & $\begin{array}{l}-0.147 \\
(0.099)\end{array}$ & $\begin{array}{c}0.140 \\
(0.216)\end{array}$ & $\begin{array}{l}-0.127 \\
(0.096)\end{array}$ & $\begin{array}{l}-0.099 \\
(0.139)\end{array}$ & $\begin{array}{l}-0.142 \\
(0.091)\end{array}$ & $\begin{array}{l}-0.085 \\
(0.099)\end{array}$ \\
\hline Ln(Non-U.S. For. Acquis. Ratio) & $\begin{array}{c}0.077 \\
(0.135)\end{array}$ & $\begin{array}{c}0.058 \\
(0.137)\end{array}$ & $\begin{array}{c}0.071 \\
(0.136)\end{array}$ & $\begin{array}{c}0.259 \\
(0.193)\end{array}$ & $\begin{array}{c}0.066 \\
(0.137)\end{array}$ & $\begin{array}{c}0.062 \\
(0.157)\end{array}$ & $\begin{array}{c}0.057 \\
(0.133)\end{array}$ & $\begin{array}{c}0.138 \\
(0.153)\end{array}$ \\
\hline U.S. Listing & $\begin{array}{l}0.164^{* *} \\
(0.073)\end{array}$ & $\begin{array}{c}0.135 \\
(0.114)\end{array}$ & $\begin{array}{l}0.164^{* * *} \\
(0.075)\end{array}$ & $\begin{array}{c}0.119 \\
(0.104)\end{array}$ & $\begin{array}{l}0.174^{* *} \\
(0.073)\end{array}$ & $\begin{array}{c}0.122 \\
(0.082)\end{array}$ & $\begin{array}{l}0.175^{* *} \\
(0.073)\end{array}$ & $\begin{array}{l}0.142^{*} \\
(0.080)\end{array}$ \\
\hline Non-U.S. Foreign Listing & $\begin{array}{c}0.152 \\
(0.108)\end{array}$ & $\begin{array}{c}0.172 \\
(0.107)\end{array}$ & $\begin{array}{c}0.145 \\
(0.111)\end{array}$ & $\begin{array}{c}0.251 \\
(0.267)\end{array}$ & $\begin{array}{c}0.154 \\
(0.109)\end{array}$ & $\begin{array}{c}0.136 \\
(0.109)\end{array}$ & $\begin{array}{c}0.167 \\
(0.108)\end{array}$ & $\begin{array}{l}0.294^{*} \\
(0.157)\end{array}$ \\
\hline U.S. Channel & $\begin{array}{l}0.086^{*} \\
(0.044)\end{array}$ & $\begin{array}{c}0.013 \\
(0.057)\end{array}$ & $\begin{array}{c}0.069 \\
(0.055)\end{array}$ & $\begin{array}{c}0.082 \\
(0.073)\end{array}$ & $\begin{array}{c}0.200 \\
(0.186)\end{array}$ & $\begin{array}{c}0.275 \\
(0.234)\end{array}$ & $\begin{array}{l}0.250^{* * * *} \\
(0.090)\end{array}$ & $\begin{array}{c}0.159 \\
(0.148)\end{array}$ \\
\hline Non-U.S. Foreign Channel & $\begin{array}{c}0.092 \\
(0.109)\end{array}$ & $\begin{array}{c}0.155 \\
(0.119)\end{array}$ & $\begin{array}{c}0.015 \\
(0.050)\end{array}$ & $\begin{array}{c}-0.014 \\
(0.068)\end{array}$ & $\begin{array}{c}0.117 \\
(0.209)\end{array}$ & $\begin{array}{c}0.015 \\
(0.350)\end{array}$ & $\begin{array}{c}-0.217^{* *} \\
(0.099)\end{array}$ & $\begin{array}{c}-0.128 \\
(0.132)\end{array}$ \\
\hline U.S. Sales Ratio*U.S. Channel & & $\begin{array}{l}0.491^{* *} \\
(0.209)\end{array}$ & & $\begin{array}{l}-0.108 \\
(0.232)\end{array}$ & & $\begin{array}{l}-1.295 \\
(0.925)\end{array}$ & & $\begin{array}{c}0.119 \\
(0.292)\end{array}$ \\
\hline Non-U.S. For. Sales Ratio*Non-U.S. Channel & & $\begin{array}{l}-0.142 \\
(0.534)\end{array}$ & & $\begin{array}{c}0.205 \\
(0.157)\end{array}$ & & $\begin{array}{c}0.154 \\
(0.689)\end{array}$ & & $\begin{array}{l}-0.048 \\
(0.254)\end{array}$ \\
\hline Ln(U.S. Acquisition Ratio)*U.S. Channel & & $\begin{array}{c}-0.191 \\
(0.181)\end{array}$ & & $\begin{array}{l}-0.374^{*} \\
(0.226)\end{array}$ & & $\begin{array}{c}-0.288 \\
(0.802)\end{array}$ & & $\begin{array}{c}-0.204 \\
(0.247)\end{array}$ \\
\hline Ln(Non-U.S. For. Acquis.)*Non-U.S. & & 0.375 & & -0.402 & & 0.210 & & \\
\hline Channel & & (1.063) & & $(0.267)$ & & $(1.530)$ & & $\begin{array}{c}-0.152 \\
(0.270)\end{array}$ \\
\hline U.S. Listing*U.S. Channel & & $\begin{array}{c}0.042 \\
(0.113)\end{array}$ & & $\begin{array}{c}0.115 \\
(0.120)\end{array}$ & & $\begin{array}{c}0.463 \\
(0.447)\end{array}$ & & $\begin{array}{c}0.178 \\
(0.130)\end{array}$ \\
\hline Non-U.S. Foreign Listing*Non-U.S. Channel & & $\begin{array}{c}-1.351^{* * * *} \\
(0.473)\end{array}$ & & $\begin{array}{c}-0.125 \\
(0.266)\end{array}$ & & $\begin{array}{c}0.174 \\
(0.604)\end{array}$ & & $\begin{array}{l}-0.286 \\
(0.191)\end{array}$ \\
\hline Adjusted R-Squared & 0.473 & 0.476 & 0.472 & 0.474 & 0.472 & 0.471 & 0.475 & 0.476 \\
\hline
\end{tabular}

***, **, * Significantly different from zero at the one, five, and ten percent levels (two-tailed test) respectively, using standard errors clustered by firm. 


\section{Table $6 \quad$ U.K. Compensation Practices around U.S. and Non-U.S. Acquisition Events}

This table presents tests of compensation changes around U.S. and non-U.S. acquisitions by U.K. firms over the period 20022007. The panels present select coefficients from executive-level fixed effects estimations of the following models:

$$
\begin{aligned}
& \text { Ln(Trend-adjusted Compensation } \left.\left.{ }_{\mathrm{it}}\right)=\alpha+\sum_{i=1}^{j} \gamma_{k} \text { Executive }_{i}+\beta_{1} \text { Ln}_{\left(\text {Assets }_{i t}\right.}\right)+\beta_{2} \text { Market-to-Book }_{i t}+\beta_{3} \text { ROA }_{i t}+\beta_{4} C F O_{i t} \\
& +\beta_{5} \text { Stock Return }_{i t}+\beta_{6} \text { Return Volatility }_{i t}+\beta_{7} \operatorname{Ln}\left(\text { Tenure }_{i t}\right)+\beta_{8} \operatorname{Ln}\left(\text { Percent Shares Held }_{i t}\right)+\beta_{9} \text { Percent Inside Directors }_{i t} \\
& \left.+\beta_{10} \operatorname{Ln}\left(\text { Board Size }_{i t}\right)+\beta_{11} \operatorname{Ln}(\text { U.S. Acquisition Ratio } i t)+\beta_{12} \text { Ln(Non-U.S. Acquisition Ratio }{ }_{i t}\right)
\end{aligned}
$$

The dependent variable, Trend-adjusted Compensation, equals the specified measure of annual compensation earned by the CEO of firm $i$ in year $t$ less the mean corresponding level of compensation reported in the Hemscott database for year $t$. These tests use the three years of compensation data centered on a U.K. firm's U.S. or non-U.S. foreign acquisition event (years $t-1$ to $t+1$ ). Executive $_{i}$ is an executive-level fixed effect to capture unobserved heterogeneity. Panel A presents tests of compensation changes around U.S. acquisition events. Total Compensation, Cash Compensation, Salary, and Bonus models are estimated using ordinary least squares. Ln(Equity Compensation) and Equity Ratio models are estimated using Tobit. Option Grant models are estimated using logit. Panel B repeats these estimations using a restricted sample of firms in which there were no CEO turnovers during the three-year window. Standard errors (in parentheses) are clustered at the executive-level. P-values on the equality of the U.S. and Non-U.S. foreign acquisition coefficients are from a t-test (one-sided).

Panel A: All U.K. firms with a U.S. or non-U.S. foreign acquisition event (2002-2007)

\begin{tabular}{|c|c|c|c|c|c|c|c|}
\hline & Ln(Total) & Ln(Cash) & Ln(Salary) & Ln(Bonus) & Ln(Equity) & Equity Ratio & Option Grant \\
\hline Ln(U.S. Acquisition Ratio) & $\begin{array}{c}0.758^{* * * *} \\
(0.351)\end{array}$ & $\begin{array}{l}0.502^{*} \\
(0.257)\end{array}$ & $\begin{array}{c}0.251 \\
(0.192)\end{array}$ & $\begin{array}{c}13.437 * * * \\
(3.406)\end{array}$ & $\begin{array}{c}7.364 \\
(5.123)\end{array}$ & $\begin{array}{c}0.228^{* *} \\
(0.110)\end{array}$ & $\begin{array}{c}0.635 \\
(0.405)\end{array}$ \\
\hline Ln(Non-U.S. Acq. Ratio) & $\begin{array}{r}-0.075 \\
(0.333)\end{array}$ & $\begin{array}{l}-0.400 \\
(0.347)\end{array}$ & $\begin{array}{c}-0.423^{* *} \\
(0.186)\end{array}$ & $\begin{array}{l}-6.271^{*} \\
(3.349)\end{array}$ & $\begin{array}{c}3.059 \\
(3.167)\end{array}$ & $\begin{array}{c}0.119 \\
(0.090)\end{array}$ & $\begin{array}{l}-0.308 \\
(0.413)\end{array}$ \\
\hline U.S. $=$ Non-U.S. p-value & 0.032 & 0.019 & 0.006 & 0.001 & 0.249 & 0.220 & 0.066 \\
\hline Fixed Effects \& Controls & Included & Included & Included & Included & Included & Included & Included \\
\hline $\mathrm{N}$ & 178 & 178 & 178 & 178 & 178 & 178 & 178 \\
\hline
\end{tabular}

\begin{tabular}{lccccccc}
\hline Dependent variable: & Ln(Total) & Ln(Cash) & Ln(Salary) & Ln(Bonus) & Ln(Equity) & Equity Ratio & Option Grant \\
\hline Ln(US Acquisition Ratio) & $0.693^{*}$ & $0.474^{*}$ & $0.255^{*}$ & $12.613^{* * *}$ & 7.078 & 0.182 & $0.758^{* *}$ \\
& $(0.364)$ & $(0.262)$ & $(0.131)$ & $(3.341)$ & $(4.522)$ & $(0.111)$ & $(0.370)$ \\
Ln(Non-U.S. Acq. Ratio) & 0.132 & -0.260 & $-0.394^{* *}$ & -3.407 & 1.546 & 0.123 & -0.378 \\
& $(0.365)$ & $(0.346)$ & $(0.193)$ & $(2.856)$ & $(3.078)$ & $(0.110)$ & $(0.445)$ \\
U.S. = Non-U.S. p-value & 0.133 & 0.041 & 0.001 & 0.001 & 0.166 & 0.722 & 0.031 \\
Fixed Effects & Included & Included & Included & Included & Included & Included & Included \\
$\mathrm{N}$ & 243 & 243 & 243 & 243 & 243 & 243 & 243 \\
\hline
\end{tabular}

Panel B: U.K. firms without CEO turnover around U.S. or non-U.S. acquisition event (2002-2007)

by executive. 


\section{Table $7 \quad$ U.K. Compensation Practices around U.S. and Non-U.S. Listing Events}

This table presents tests of compensation changes around U.S. and non-U.S. listings of U.K. firms over the period $1998-2007$. The panels present select coefficients from executive-level fixed effects estimations of the following models:

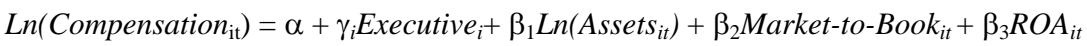

$$
\begin{aligned}
& +\beta_{4} \text { U.S. Listing Event }{ }_{i t}+\beta_{5} \text { Non-U.S. Foreign Listing Event }{ }_{i t}+\varepsilon_{\mathrm{it}}
\end{aligned}
$$

For $\operatorname{Ln}$ (Cash Compensation), $\operatorname{Ln}$ (Salary), and $\operatorname{Ln}$ (Bonus), the dependent variable equals the specified measure of annual compensation earned by the CEO of firm $i$ in year $t$ less the mean corresponding level of compensation reported in the Hemscott database for year $t$. Because Hemscott does not provide equity compensation data for the first part of the sample (1998-2002), Ln(Total Compensation) and Equity Ratio are not trend-adjusted. U.S. Listing Event ${ }_{i t}$ (Non-U.S. Foreign Listing Event it $_{\text {) }}$ equals one if year $t$ corresponds to the year after a U.S. (non-U.S.) foreign listing. Executive $e_{i}$ is an executive-level fixed effect to capture unobserved heterogeneity. These tests use three years of compensation data centered on the listing event (years $t-1$ to $t+1$ ). Total Compensation, Cash Compensation, Salary, and Bonus models are estimated using ordinary least squares. Ln(Equity Compensation) and Equity Ratio models are estimated using Tobit. Option Grant models are estimated using logit. Panel B repeats these tests using a restricted sample of firms in which there were no CEO turnovers during the three-year window. Standard errors (in parentheses) are clustered at the executive-level. P-values on the equality of the U.S. and Non-U.S. foreign listing coefficients are from a t-test (one-sided).

Panel A: All U.K. firms with a U.S. or non-U.S. foreign listing event (1998-2007)

\begin{tabular}{lccccccc}
\hline & Ln(Total) & Ln(Cash) & Ln(Salary) & Ln(Bonus) & Ln(Equity) & Equity Ratio & Option Grant \\
\hline U.S. Listing & 0.092 & $0.181^{* * *}$ & $0.144^{* * *}$ & 0.101 & -0.487 & -0.029 & -0.102 \\
Non-U.S. Listing & $(0.059)$ & $(0.056)$ & $(0.039)$ & $(0.709)$ & $(0.746)$ & $(0.032)$ & 0.067 \\
& -0.126 & 0.135 & $0.152^{* *}$ & 1.218 & -0.446 & $-0.154^{*}$ & -0.002 \\
& $(0.182)$ & $(0.175)$ & $(0.068)$ & $(1.821)$ & $(2.039)$ & $(0.088)$ & 0.170 \\
Fixed Effects & Included & Included & Included & Included & Included & Included & Included \\
U.S. = Non-U.S. p-value & 0.108 & 0.789 & 0.908 & 0.545 & 0.984 & 0.069 & 0.561 \\
N & 186 & 186 & 186 & 186 & 186 & 186 & 186 \\
\hline
\end{tabular}

Panel B: U.K. firms without CEO turnover around U.S. or non-U.S. listing event (1998-2007)

\begin{tabular}{|c|c|c|c|c|c|c|c|}
\hline & Ln(Total) & Ln(Cash) & Ln(Salary) & Ln(Bonus) & Ln(Equity) & Equity Ratio & Option Grant \\
\hline U.S. Listing & $\begin{array}{c}0.083 \\
(0.059)\end{array}$ & $\begin{array}{l}0.180^{* * *} \\
(0.057)\end{array}$ & $\begin{array}{l}0.144^{* * *} \\
(0.038)\end{array}$ & $\begin{array}{c}0.079 \\
(0.723)\end{array}$ & $\begin{array}{l}-0.573 \\
(0.765)\end{array}$ & $\begin{array}{l}-0.034 \\
(0.033)\end{array}$ & $\begin{array}{l}-0.110 \\
(0.069)\end{array}$ \\
\hline Non-U.S. Listing & $\begin{array}{l}-0.114 \\
(0.201)\end{array}$ & $\begin{array}{c}0.193 \\
(0.198)\end{array}$ & $\begin{array}{l}0.198^{* *} \\
(0.076)\end{array}$ & $\begin{array}{c}1.608 \\
(2.012)\end{array}$ & $\begin{array}{l}-0.243 \\
(2.208)\end{array}$ & $\begin{array}{l}-0.163 \\
(0.098)\end{array}$ & $\begin{array}{c}0.013 \\
(0.184)\end{array}$ \\
\hline Fixed Effects \& Controls & Included & Included & Included & Included & Included & Included & Included \\
\hline U.S. = non-U.S. p-value & 0.158 & 0.949 & 0.239 & 0.228 & 0.879 & 0.085 & 0.505 \\
\hline $\mathrm{N}$ & 168 & 168 & 168 & 168 & 168 & 168 & 168 \\
\hline
\end{tabular}

by executive. 


\section{Table 8 Evidence on Relative Pay Disparity between U.K. Firms and Propensity-Score Matched U.S. Firms Conditional upon Extent of U.S. Market Activities}

This table presents select coefficients from various pooled, cross-sectional estimations of the following model:

Pay Disparity $_{\mathrm{it}}=\alpha+\sum_{\mathrm{k}=1}^{\mathrm{n}} \gamma_{\mathrm{k}}$ Industry $_{\mathrm{k}}+\sum_{\mathrm{t}=1}^{4} \mathrm{Year}_{\mathrm{t}}+\beta_{1} d_{-} L n\left(\right.$ Assets $\left._{i t}\right)+\beta_{2} d_{-}$Market-to-Book ${ }_{i t}+\beta_{3} d_{-} R O A_{i t}+\beta_{4} d_{-} C F O_{i t}$

$+\beta_{5} d \_$Stock Return ${ }_{i t}+\beta_{6} d \_$Return Volatility ${ }_{i t}+\beta_{7} d \_$Ln $\left(\right.$Tenure $\left._{i t}\right)+\beta_{8} d \_$Ln $\left(\right.$Percent Shares Held $\left._{i t}\right)+\beta_{9} d \_$Percent Inside

Directors $_{i t}+\beta_{10} d \_L n\left(\right.$ Board Size $\left._{i t}\right)+\beta_{11} d \_U . S$. Sales Ratio ${ }_{i t}+\beta_{12} d \_$Non-U.S. Foreign Sales Ratio ${ }_{i t}+\beta_{13} d \_L n(U . S$. Acquisition

Ratio $)_{i t}+\beta_{14} d \_L n(N o n-U . S \text {. Foreign Acquisition Ratio })_{i t}+\beta_{15} d \_$U.S. Listing $i t+\beta_{16} d \_$Non-U.S. Foreign Listing ${ }_{i t}+\beta_{17} d \_U . S$.

Board Experience $_{i t}+\beta_{18} d_{-}$Non-U.S. Foreign Board Experience $e_{i t}+\varepsilon_{\mathrm{it}}$

The dependent variable, Pay Disparity, equals the natural logarithm of the total annual compensation earned by the CEO of a propensity-score matched U.S. firm in year $t$ minus the natural logarithm of the total annual compensation of U.K. firm $i$ in year $t$. All independent variables are the difference between the realizations of the U.S. matched firm-year and the U.K. firm-year observation (denoted by the " $d_{-}$" prefix). Panel B presents estimations analogous to Tables 6 and 7 using our sample of U.S. and non-U.S. acquisition and listing events. All models are estimated using ordinary least squares. Standard errors (in parentheses) are clustered at the firm level.

Panel A: Pooled, cross-sectional tests

\begin{tabular}{|c|c|c|c|c|}
\hline Foreign Market Interaction: & Sales & Acquisition & Listing & $\begin{array}{c}\text { All Market } \\
\text { Interactions }\end{array}$ \\
\hline U.S. Sales Ratio & $\begin{array}{c}-0.813^{* * *} \\
(0.142)\end{array}$ & & & $\begin{array}{c}-0.784 * * * \\
(0.164)\end{array}$ \\
\hline Non-U.S. Foreign Sales Ratio & $\begin{array}{c}-0.057 \\
(0.099)\end{array}$ & & & $\begin{array}{l}-0.010 \\
(0.105)\end{array}$ \\
\hline Ln(U.S. Acquisition Ratio) & & $\begin{array}{c}-0.391^{* *} \\
(0.158)\end{array}$ & & $\begin{array}{c}0.052 \\
(0.178)\end{array}$ \\
\hline Ln(Non-U.S. For. Acq. Ratio) & & $\begin{array}{c}-0.190 \\
(0.204)\end{array}$ & & $\begin{array}{c}-0.111 \\
(0.216)\end{array}$ \\
\hline U.S. Listing & & & $\begin{array}{c}-0.187 * * * \\
(0.069)\end{array}$ & $\begin{array}{l}-0.086 \\
(0.072)\end{array}$ \\
\hline Non-U.S. Foreign Listing & & & $\begin{array}{c}-0.145 \\
(0.115)\end{array}$ & $\begin{array}{l}-0.108 \\
(0.117)\end{array}$ \\
\hline U.S. = Non-U.S. Sales p-value & 0.001 & & & 0.002 \\
\hline U.S. = Non-U.S. Acquis. p-value & & 0.231 & & 0.876 \\
\hline U.S. = Non-U.S. Listing p-value & & & 0.761 & 0.577 \\
\hline Control Variables \& Fixed Effects & Included & Included & Included & Included \\
\hline Adjusted R-Squared & 0.423 & 0.413 & 0.414 & 0.423 \\
\hline $\mathrm{N}$ & 1,543 & 1,543 & 1,543 & 1,543 \\
\hline
\end{tabular}

Panel B: Event tests

\begin{tabular}{|c|c|c|c|c|}
\hline Foreign Event Variable: & \multicolumn{2}{|c|}{ Ln(Acquisition Ratio) } & \multicolumn{2}{|c|}{ Listing } \\
\hline & All Events & No Turnover & All Events & No Turnover \\
\hline U.S. Event Variable & $\begin{array}{c}-1.644^{*} \\
(0.895)\end{array}$ & $\begin{array}{c}-1.608^{*} \\
(0.912)\end{array}$ & $\begin{array}{c}0.271^{*} \\
(0.148)\end{array}$ & $\begin{array}{c}0.233 \\
(0.156)\end{array}$ \\
\hline Non-U.S. Foreign Event Variable & $\begin{array}{c}0.503 \\
(0.870)\end{array}$ & $\begin{array}{c}0.496 \\
(0.883\end{array}$ & $\begin{array}{c}0.022 \\
(0.510)\end{array}$ & $\begin{array}{c}0.047 \\
(0.677)\end{array}$ \\
\hline U.S. = Non-U.S. p-value & 0.047 & 0.059 & 0.643 & 0.790 \\
\hline Control Variables \& Fixed Effects & Included & Included & Included & Included \\
\hline Adjusted R-squared & 0.441 & 0.443 & 0.286 & 0.291 \\
\hline $\mathrm{N}$ & 243 & 243 & 186 & 168 \\
\hline
\end{tabular}

***, **, * Significantly different from zero at the one, five, and ten percent levels (two-tailed test) respectively, using standard errors clustered by firm. 